\title{
Developing a Climate-Induced Social Vulnerability Index for Urban Areas: A Case Study of East Tennessee
}

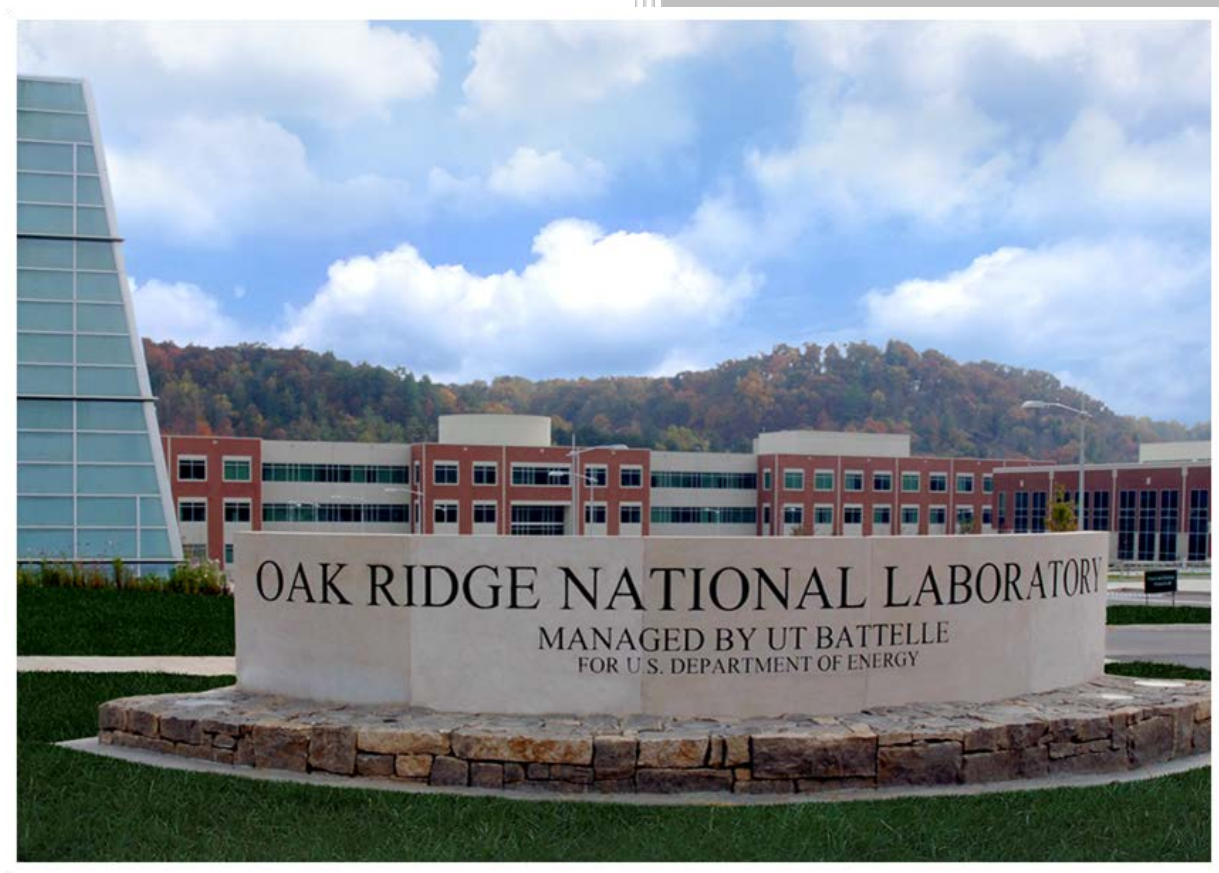

Thomaz Carvalhaes

Olufemi Omitaomu

September 2017 


\title{
DOCUMENT AVAILABILITY
}

Reports produced after January 1, 1996, are generally available free via US Department of Energy (DOE) SciTech Connect.

\section{Website http://www.osti.gov/scitech/}

Reports produced before January 1, 1996, may be purchased by members of the public from the following source:

\author{
National Technical Information Service \\ 5285 Port Royal Road \\ Springfield, VA 22161 \\ Telephone 703-605-6000 (1-800-553-6847) \\ TDD 703-487-4639 \\ Fax 703-605-6900 \\ E-mail info@ntis.gov \\ Website http://www.ntis.gov/help/ordermethods.aspx
}

Reports are available to DOE employees, DOE contractors, Energy Technology Data Exchange representatives, and International Nuclear Information System representatives from the following source:

Office of Scientific and Technical Information

PO Box 62

Oak Ridge, TN 37831

Telephone 865-576-8401

Fax 865-576-5728

E-mail reports@osti.gov

Website http://www.osti.gov/contact.html

This report was prepared as an account of work sponsored by an agency of the United States Government. Neither the United States Government nor any agency thereof, nor any of their employees, makes any warranty, express or implied, or assumes any legal liability or responsibility for the accuracy, completeness, or usefulness of any information, apparatus, product, or process disclosed, or represents that its use would not infringe privately owned rights. Reference herein to any specific commercial product, process, or service by trade name, trademark, manufacturer, or otherwise, does not necessarily constitute or imply its endorsement, recommendation, or favoring by the United States Government or any agency thereof. The views and opinions of authors expressed herein do not necessarily state or reflect those of the United States Government or any agency thereof. 
Computational Science and Engineering Division Geographic Information Science and Technology Group

\title{
DEVELOPING A CLIMATE-INDUCED SOCIAL VULNERABILITY INDEX FOR URBAN AREAS: A CASE STUDY OF EAST TENNESSEE
}

\author{
Thomaz Carvalhaes and Olufemi Omitaomu
}

Date Published: September 2017

Prepared by

OAK RIDGE NATIONAL LABORATORY

Oak Ridge, TN 37831-6283

managed by

UT-BATTELLE, LLC

for the

US DEPARTMENT OF ENERGY

under contract DE-AC05-00OR22725 



\section{CONTENTS}

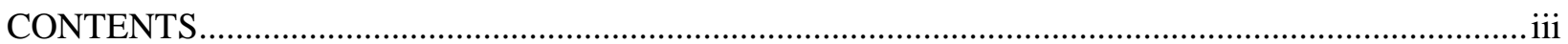

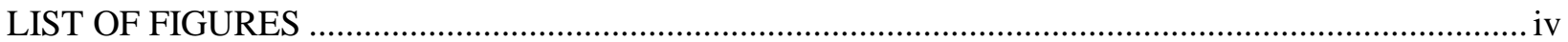

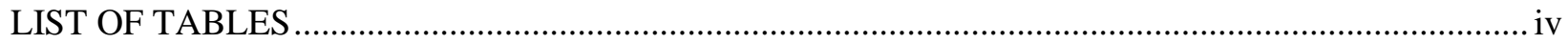

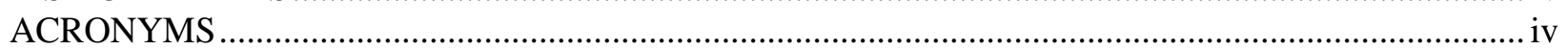

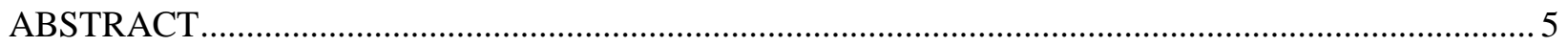

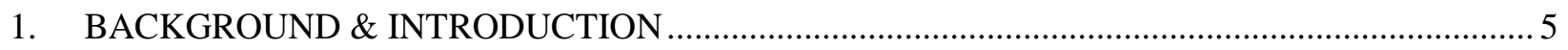

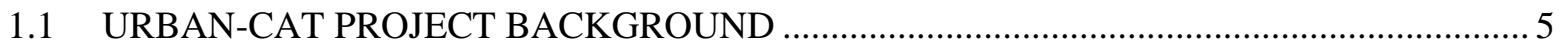

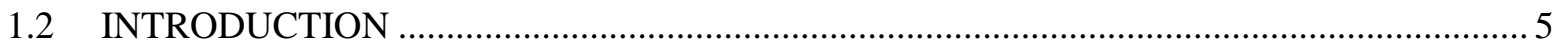

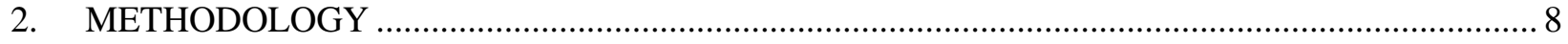

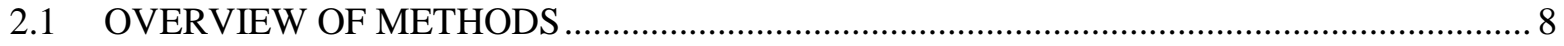

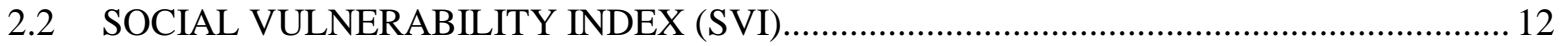

2.3 CLIMATE-INDUCED SOCIAL VULNERABILITY INDEX (CSVI) ................................... 12

2.4 DATA-IMPOSED LIMITATIONS \& UNCERTAINTIES …............................................... 13

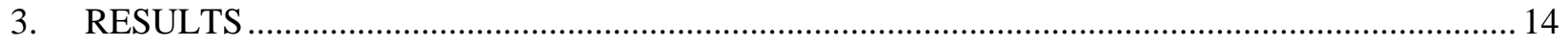

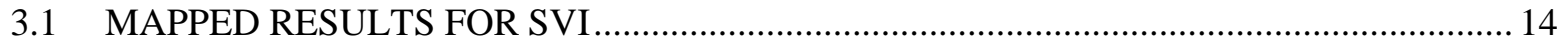

3.2 INCORPORATION OF SVI AND CSVI RESULTS INTO URBAN-CAT ........................... 16

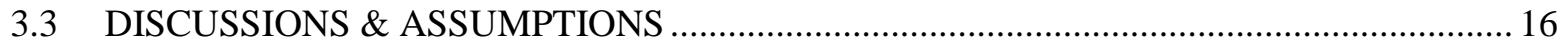

3.4 IMPLICATIONS OF SOCIAL VULNERABILITY IN IMPLEMENTATION

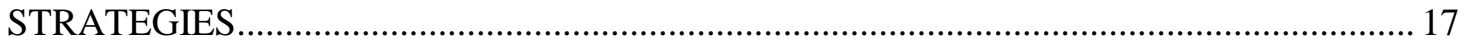

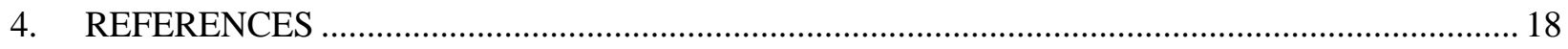

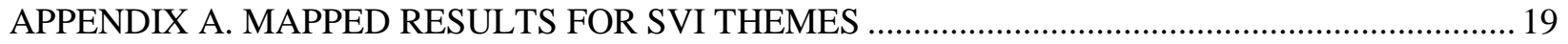




\section{LIST OF FIGURES}

Fig. 1. Bias-corrected CCSM4 Climate Model for 85th percentile daily precipitation events in the Knox County watershed (HUC-12). (a) Historical projection from 1980 to 2005. (b) Future projection from 2025-2050. According to the CCSM4 model, greater rainfall values are expected for 85th percentile events in this watershed.

Fig. 2. Workflow for the Climate-Induced Social Vulnerability Index. Theme SVIs are in green, orange, purple, and cyan colored boxes, while the complete SVI, Climate Index, and CSVI are in red. See Table 2 for indicator calculation and as a supplement to this figure.

Fig. 3. (a) Location and extent of East Tennessee area of interest, and mapped result of the overall combined SVI for (b) Roane County (c) Anderson County (d) Union County (e) Grainger County (f) Jefferson (g) Sevier County (h) Blount County (i) Monroe County (j) Loudon (k) Knox County. SVI scores approaching 1 describe a greater social vulnerability whereas scores approaching 0 describe a lesser vulnerability.

Fig.4. Overall combined SVI shown for downtown Knoxville, Tennessee as displayed in Urban-CAT.

Appendix A Figures. (a) Socioeconomic Status Theme indicators include poverty, unemployment, income, and no high school diploma. (b) Household Composition and Disability Theme indicators include residents age 65 and older, residents age 17 and younger, residents older than 5 years with a disability, and single-parent households. (c) Minority Status and Language Theme indicators include minority status and households that speak English "less than well”. (d) Housing and Transportation Theme indicators include multi-unit structures, mobile homes, crowding, no vehicles, and group quarters.

\section{LIST OF TABLES}

Table 1. Difference in rainfall depths for high percentile precipitation events between the historical and future projections from 10 climate models (adapted from Sylvester, Omitaomu, \& Parish, 2016). The greatest increase occurs in the 95th percentile.

Table 2. List of the 15 ACS 2008-2012 variables used as indicators for the SVI and calculation methods to obtain final indicators to be used in the index. Colors correspond to the workflow diagram in Fig. 2.

\section{ACRONYMS}

$\begin{array}{ll}\text { CCSM4 } & \text { Community Climate System Model } \\ \text { CDC } & \text { Centers for Disease Control and Prevention } \\ \text { CSVI } & \text { Climate-Induced Social Vulnerability Index } \\ \text { EJSCREEN } & \text { Environmental Justice Screening and Mapping Tool } \\ \text { EPA } & \text { Environmental Protection Agency } \\ \text { ETindex } & \text { East Tennessee Index } \\ \text { GEOID } & \text { Geographic Identifier } \\ \text { GI } & \text { Green Infrastructure } \\ \text { GRASP } & \text { Geospatial Research, Analysis, and Services Program } \\ \text { HVRI } & \text { Hazards \& Vulnerability Research Institute (University of South Carolina) } \\ \text { LDRD } & \text { Laboratory Directed Research and Development } \\ \text { ORNL } & \text { Oak Ridge National Laboratory } \\ \text { SoVI } & \text { Social Vulnerability Index to Environmental Hazards (by HVRI) } \\ \text { SVI } & \text { Social Vulnerability Index } \\ \text { Urban-CAT } & \text { Urban Climate Adaptation Tool }\end{array}$




\begin{abstract}
Census American Community Survey 2008-2012 data are used to construct a spatially explicit Social Vulnerability Index (SVI) for the East Tennessee area. A Climate-Induced Social Vulnerability Index (CSVI) is to be developed as a combination of the SVI and a Climate Index. A method is replicated and adapted to derive a custom SVI by Census tract for the counties participating in the East Tennessee Index, and a Climate Index will be developed for the same area based on indicators for climate hazards. The resulting datasets are to be exported as a raster to be integrated and combined within the Urban Climate Adaptation Tool (Urban-CAT) to act as an indicator for communities which may be differentially vulnerable to changes in climate. Results for the SVI are mapped separately from the complete CSVI in this document as results for the latter are in development.
\end{abstract}

\title{
1. BACKGROUND \& INTRODUCTION
}

\subsection{URBAN-CAT PROJECT BACKGROUND}

As part of a Laboratory Directed Research and Development (LDRD) project, Oak Ridge National Laboratory (ORNL) has partnered with the City of Knoxville and Knox County to investigate climate change and possible adaptation strategies for mid-sized urban areas. Namely, the Urban Climate Adaptation Tool (Urban-CAT) serves as a decision analysis web-based tool used to map possible climaterelated risks and optimize planning strategies. The tool leverages climate and population projections along with socioeconomic and infrastructure data in an interactive spatial environment to visualize, model, and analyze potential risks and planning options to reduce these risks. During development, the initial capability of the tool focuses on optimal locations for implementing green infrastructure as a measure of stormwater and flood management in Knoxville, TN. In this way, stormwater and flooding are the pilot events, Knoxville is the pilot city, and green infrastructure is the pilot mitigation. Future development will expand these capabilities to include other emerging cities, climate change related events and adaptation options, as well as possible improvements and additions to the roster of indicators. This document describes the development of a Social Vulnerability Index (SVI) for the East Tennessee Index* areas of interest (i.e. ETindex reach) as an indicator for communities which may be socially vulnerable to climate change.

\subsection{INTRODUCTION}

Several climate models have shown that a changing climate can potentially put communities in East Tennessee at risk to extreme weather including possible flooding from high intensity precipitation events (Fig. 1; Table 1; Sylvester, Omitaomu, Parish, \& Allen, 2016). Urban-CAT is being designed to assist decision makers in strategically adapting to these changes by adopting a risk-based spatial model. Risks are assessed via indicators that describe stressors and vulnerabilities. Understanding vulnerabilities can show communities which vulnerable components can enhance a stressor making an event that much more hazardous. For example, a heat wave superimposed upon a heat island would compound the effects of temperature and potentially pose significantly more risk than a heat wave over a lesser developed area. Currently, the tool uses indicators that consider physical phenomena to spatially quantify and visualize vulnerability to the potential impacts of these events (e.g. increased frequency and intensity of rainfall events, urban heat islands).

\footnotetext{
${ }^{*}$ ETindex.org
} 


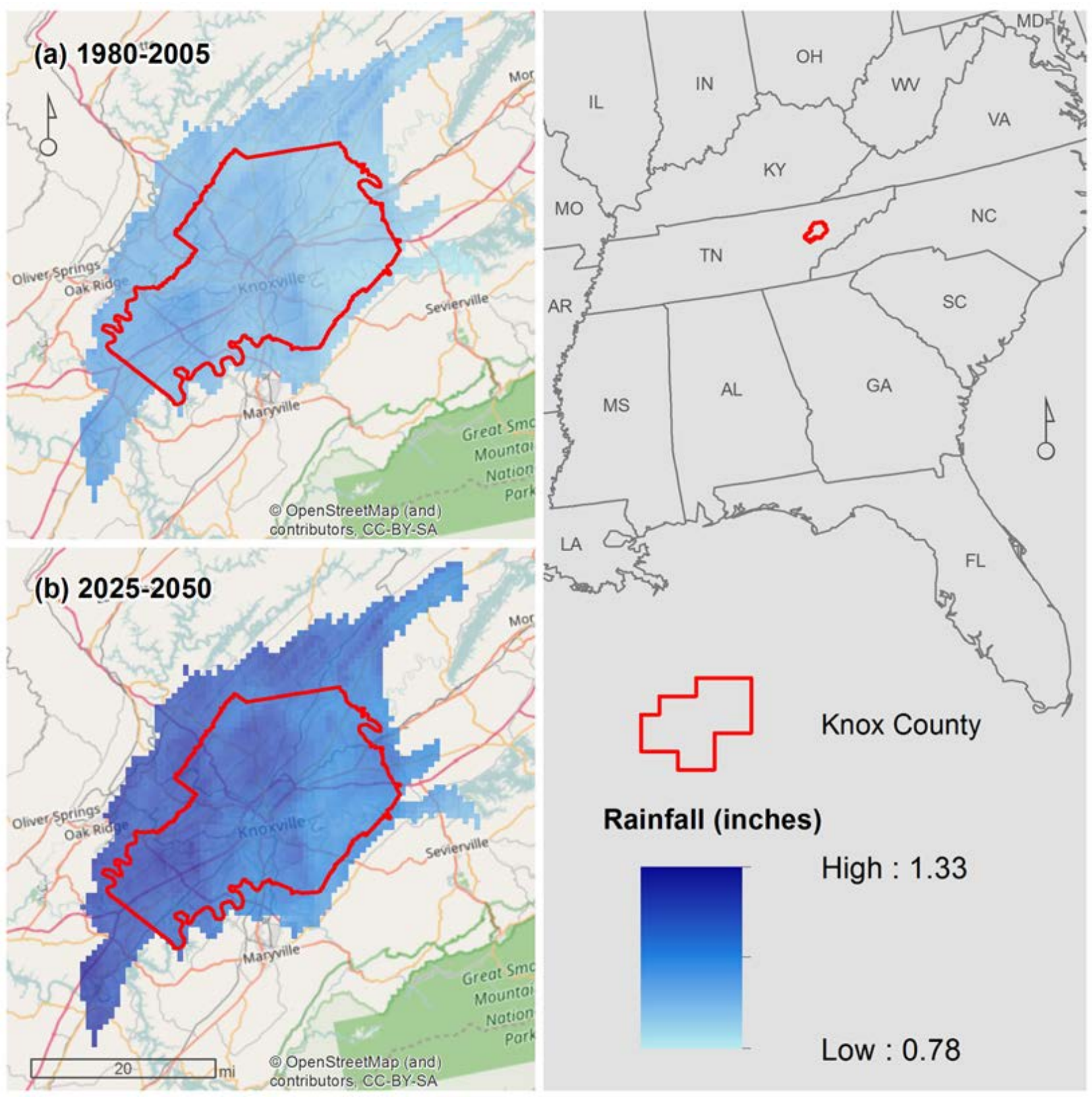

Fig. 1. Bias-corrected CCSM4 Climate Model for 85th percentile daily precipitation events in the Knox County watershed (HUC-12). (a) Historical projection from 1980 to 2005. (b) Future projection from 2025-2050. According to the CCSM4 model, greater rainfall values are expected for 85th percentile events in this watershed. 
Table 1. Difference in rainfall depths for high percentile precipitation events between the historical and future projections from 10 climate models (adapted from Sylvester, Omitaomu, \& Parish, 2016). The greatest increase occurs in the 95th percentile.

\begin{tabular}{|c|c|c|c|c|c|c|}
\hline \multirow[t]{2}{*}{ Model } & \multicolumn{6}{|c|}{$\begin{array}{c}\text { Between Past and Future } \\
\text { Event Rainfall linches) }\end{array}$} \\
\hline & $\underline{\text { 75th Percentile }}$ & 80th Percentile & 85th Percentile & 90th Percentile & & 5th Percentile \\
\hline ACCESS & 0.05 & 0.07 & 0.08 & 0.10 & & 0.12 \\
\hline $\mathrm{BCC}$ & 0.05 & 0.07 & 0.08 & 0.12 & & 0.26 \\
\hline $\cos M 4$ & 0.10 & 0.14 & 0.22 & 0.36 & & 0.64 \\
\hline $\mathrm{CMCC}$ & 0.25 & 0.20 & 0.16 & 0.38 & & 0.65 \\
\hline FGOALS & -0.02 & -0.02 & -0.02 & -0.02 & & 0.01 \\
\hline GFDL & 0.05 & 0.06 & 0.09 & 0.14 & & 0.31 \\
\hline IPSL & 0.03 & 0.04 & 0.06 & 0.12 & & 0.23 \\
\hline MPI & 0.15 & 0.19 & 0.28 & 0.46 & & 1.07 \\
\hline MRI & 0.04 & 0.05 & 0.08 & 0.13 & & 0.19 \\
\hline NorESM & 0.02 & 0.04 & 0.06 & 0.10 & & 0.28 \\
\hline Average & 0.07 & 0.08 & 0.11 & 0.19 & & 0.38 \\
\hline
\end{tabular}

However, the ability of a given community to cope with these impacts can be described in terms of resilience, which can be defined as a community's ability to anticipate, prepare, endure, and recover from a hazardous event (Henstra, 2012). Although a series of communities may incur the same event and be equally or similarly vulnerable to its direct impacts, the resilience of one particular community may substantially differ from another due to social factors (Cutter, 1996). The social vulnerability of a community then, is a very relevant consideration in resilience planning and climate adaptation strategies.

To represent and integrate a social consideration for climate change adaptation into Urban-CAT, we construct a Climate-Induced Social Vulnerability Index (CSVI) for counties that fall within the ETindex areas of interest, plus Grainger County since it falls within the common watershed. The methodology used is based on established methods by the University of South Carolina's Hazards and Vulnerability Research Institute (HVRI) and the Centers for Disease Control and Prevention (CDC) ${ }^{\dagger}$. Cutter and colleagues at HVRI have done seminal work which has produced a continually revised Social Vulnerability Index for environmental hazards (SoVI) $)^{\ddagger}$. Revisions from the original 2003 index are mainly re-evaluations of indicators used for the index as new potential variables emerge from the U.S. Census American Community Survey products, as well as developments in the knowledge base of vulnerability research. The HVRI methodology begins with a thorough review of social indicators to hazards vulnerability that can be taken from available Census variables and some ancillary sources, followed by a principal components analysis to reduce the original variables to 11 independent factors. The factors are weighted by county and then assembled in an additive model to come up with a composite vulnerability score per Census County for the contiguous United States.

Building on HVRI's work, the CDC's Geospatial Research, Analysis, and Services Program (GRASP) used a similar model per Census tract. A percentile-rank approach was applied to 15 Census-based variables selected as indicators (Flanagan et al., 2011; CDC, 2016). The term “indicator” is used in the

\footnotetext{
† See http://svi.cdc.gov/ for more information.

‡ See http://artsandsciences.sc.edu/geog/hvri/ for more information.
} 
respective literature to define variables that can be used to represent broader social concepts ${ }^{\S}$. For example, “Age 65 or older" and “Age 17 or younger” are two Census variables used as indicators that describe how a certain household composition may contribute to a higher vulnerability. These indicators are grouped into "Themes" which produce separate indices that sum to the overall combined Social Vulnerability Index (SVI). The Environmental Protection Agency’s (EPA) Environmental Justice Mapping and Screening Tool (EJSCREEN) is another example of a tool that combines environmental and demographic indicators to form an environmental justice index to identify and address disproportionately high human health or environmental effects (EPA, 2015).

After reviewing these approaches, the CDC methodology was adapted to the following East Tennessee counties: Anderson, Blount, Jefferson, Grainger, Knox, Loudon, Monroe, Roane, Sevier, and Union. This decision is based mainly on the vintage and relevance of the Census data used for indicators, and since tract-level analysis is more practical in terms of implementation strategies for the ETindex geographical scope.

\section{METHODOLOGY}

\subsection{OVERVIEW OF METHODS}

Generally, previous SVI methods rely on an additive approach based on Census variables used as indicators. The SVI however, is in turn an indicator for social vulnerability within Urban-CAT, as are the data for physical phenomena. For the approach adopted here, percentiles are derived from indicators drawn from Census American Community Survey (ACS) 2008-2012 variables. These values are summed and normalized to produce thematic and overall SVIs. The overall combined SVI is an aggregate of four SVI Themes: Socioeconomic Status, Household Composition \& Disability, Minority Status \& Language, and Housing \& Transportation. In this document, the overall SVI will primarily be referred to as such for clarity or simply as "SVI", and the thematic versions always referred to collectively as the four Theme SVIs. In the future the CSVI will be a combination of this SVI and a Climate Index made up of physical climate-based indicators which can be used dynamically in Urban-CAT as a whole CSVI or by the four aforementioned Themes. This workflow is summarized in Fig. 2.

\footnotetext{
$\S$ See Cutter, Boruff, \& Shirley, 2003, page 245 for more information and as an example.
} 


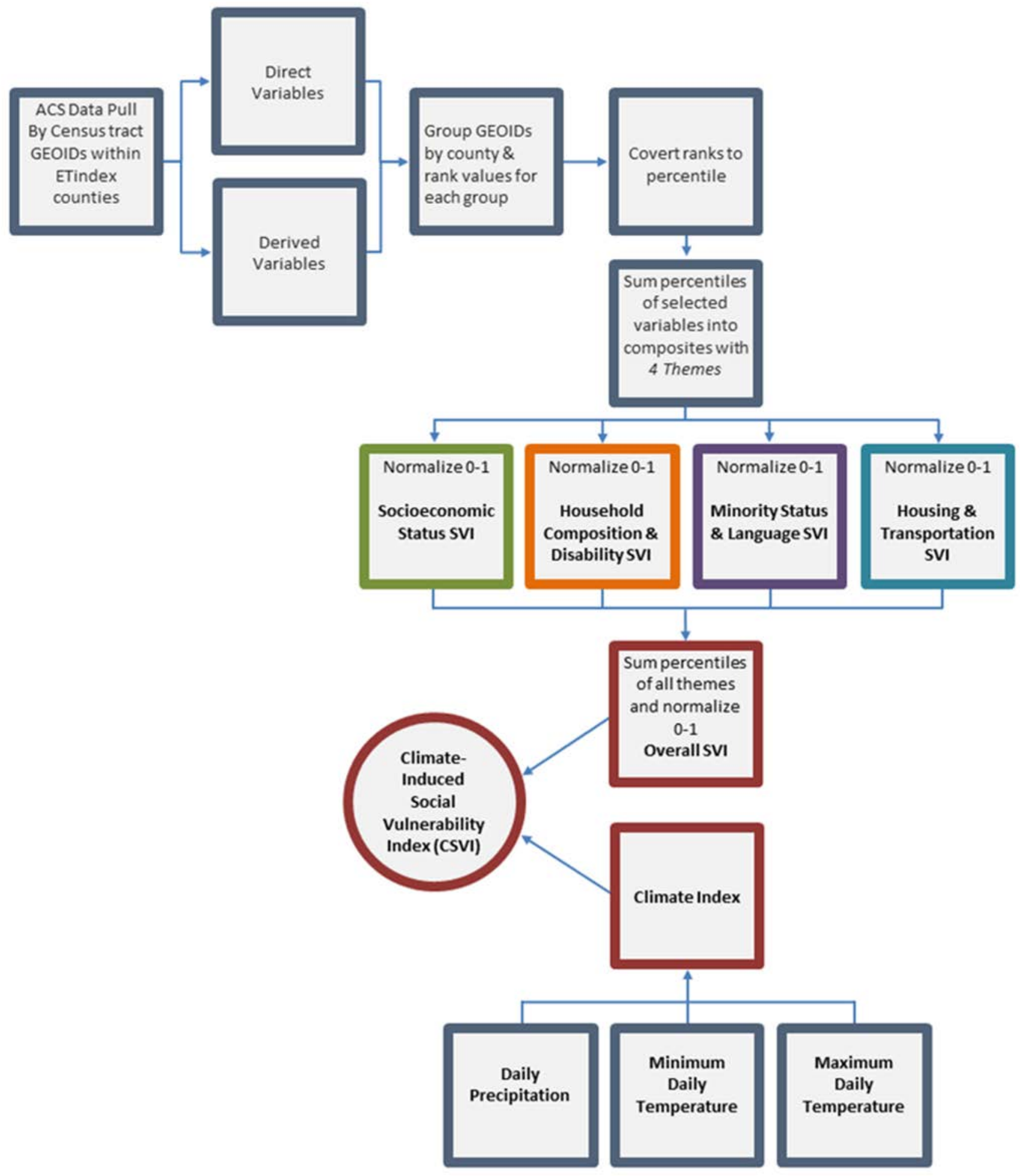

Fig. 2. Workflow for the Climate-Induced Social Vulnerability Index. Theme SVIs are in green, orange, purple, and cyan colored boxes, while the overall combined SVI, Climate Index, and CSVI are in red. See Table 2 for indicator calculation and as a supplement to this figure. 
Table 2. List of the 15 ACS 2008-2012 variables used as indicators for the SVI and calculation methods to obtain final indicators to be used in the index. Colors correspond to the workflow diagram in Fig. 2.

\begin{tabular}{|c|c|c|c|}
\hline Indicator & SVI Theme & ACS Variables & ACS Variable Fields \& Indicator Calculation \\
\hline $\begin{array}{l}\text { \% Individuals } \\
\text { below poverty }\end{array}$ & \multirow{6}{*}{ 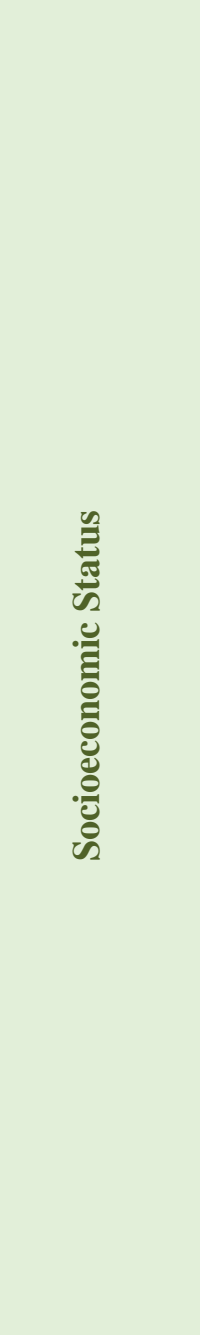 } & $\begin{array}{l}\text { Ratio of income } \\
\text { to poverty level } \\
\text { in the past } 12 \\
\text { months } \\
\text { Universe: } \\
\text { Population for } \\
\text { whom poverty } \\
\text { status is } \\
\text { determined }\end{array}$ & $\frac{\text { "Under } 0.50 "+\text { " } 0.50 \text { to } 0.99 "}{\text { Total Population }}$ \\
\hline \multirow{2}{*}{$\begin{array}{l}\text { \% Civilian } \\
\text { unemployed }\end{array}$} & & \multirow{2}{*}{$\begin{array}{l}\text { Sex by age by } \\
\text { employment } \\
\text { status for the } \\
\text { population } 16 \\
\text { years and over }\end{array}$} & $\begin{array}{c}\text { Sum of age groups "16 to } 19 \text { years" and older for males and females } \\
\text { with "unemployed status" }\end{array}$ \\
\hline & & & Population 16 and over \\
\hline $\begin{array}{l}\text { Per capita } \\
\text { income }\end{array}$ & & $\begin{array}{l}\text { Per capita } \\
\text { income in the } \\
\text { past } 12 \text { months } \\
\text { (in } 2012 \\
\text { inflation- } \\
\text { adjusted } \\
\text { dollars) }\end{array}$ & Direct variable \\
\hline \multirow[t]{2}{*}{$\begin{array}{l}\text { \% Persons no } \\
\text { high school } \\
\text { diploma }\end{array}$} & & \multirow[t]{2}{*}{$\begin{array}{l}\text { Educational } \\
\text { attainment for } \\
\text { the population } \\
25 \text { years and } \\
\text { over }\end{array}$} & $\begin{array}{c}\text { "No schooling completed" + "nursery school" + "kindergarten" + } \\
\text { "1st grade" + "2nd grade" + "3rd grade" + "4th grade" } \\
\text { "5th grade"+ "6th grade" + "7th grade" + "8th grade" + "9th grade" } \\
\text { + "10th grade" + "11th grade" + "12th grade, no diploma" } \\
\end{array}$ \\
\hline & & & Population 25 years and over \\
\hline \multirow{2}{*}{$\begin{array}{c}\text { \% Persons } \\
+65\end{array}$} & \multirow{6}{*}{ 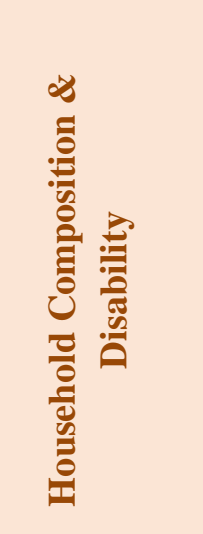 } & \multirow{2}{*}{ Sex by age } & Sum of age groups "65 to 66 years" and above for males and females \\
\hline & & & Total Population \\
\hline \multirow[t]{2}{*}{$\begin{array}{l}\% 17 \text { or } \\
\text { younger }\end{array}$} & & \multirow[t]{2}{*}{ Sex by age } & $\begin{array}{c}\text { Sum of Male and Female: } \\
\text { "under } 5 \text { years" + "5 to } 9 \text { years" + "10 to } 14 \text { years" } \\
\text { + "15 to } 17 \text { years" }\end{array}$ \\
\hline & & & Total Population \\
\hline \multirow[t]{2}{*}{$\begin{array}{l}\% \text { Persons }+5 \\
\text { old with } \\
\text { Disability }\end{array}$} & & \multirow[t]{2}{*}{$\begin{array}{l}\text { Sex by age by } \\
\text { disability status }\end{array}$} & $\begin{array}{l}\text { Sum of Male and Female with disability for age groups: } \\
\text { "5 to } 17 \text { years" and remaining age groups over } 18 \text { years } \\
\text { Total Ponulation }\end{array}$ \\
\hline & & & Total Population \\
\hline
\end{tabular}

Table 2. (continued) 


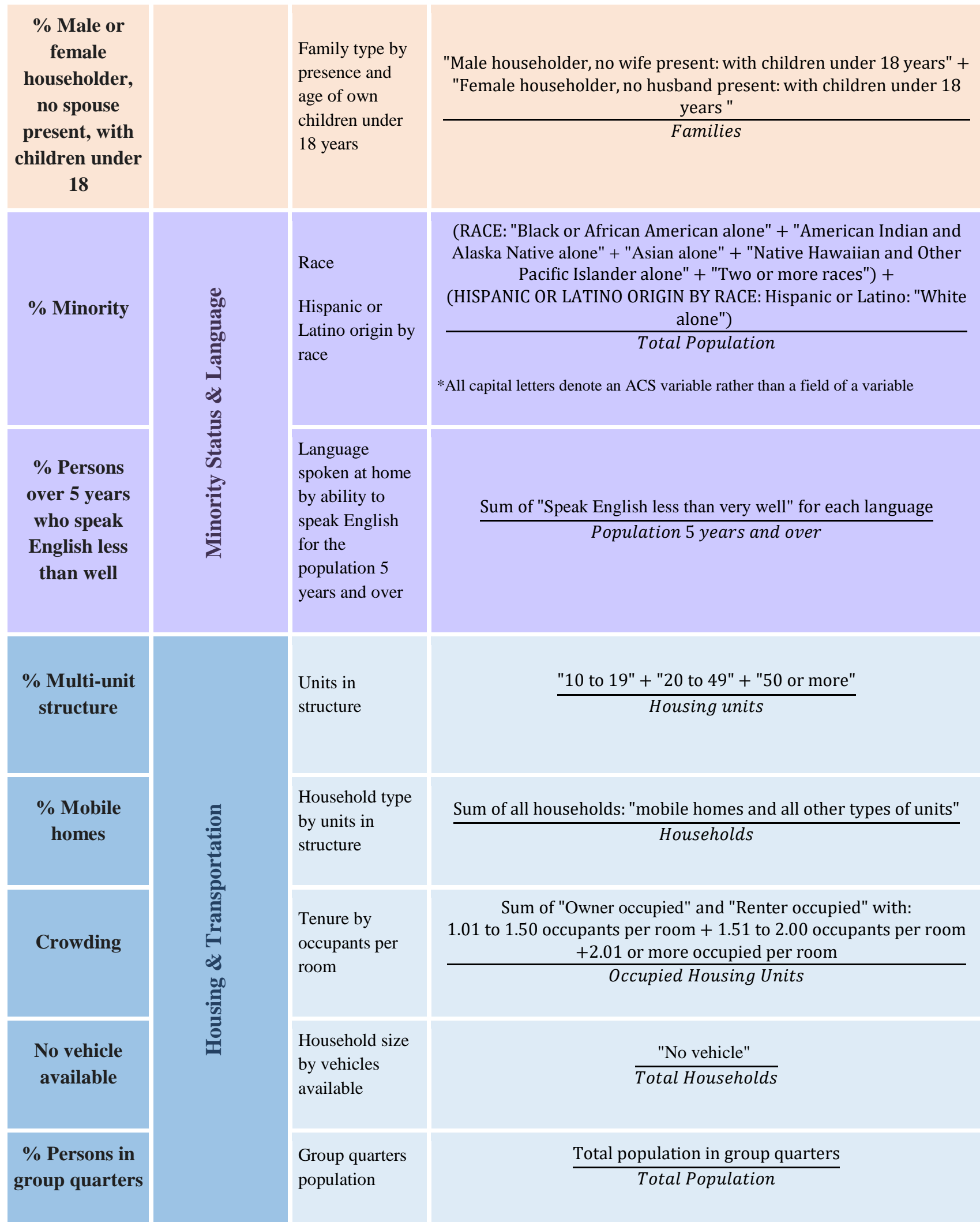


Since the geographic scope of the HVRI and CDC indices encompasses at least the contiguous United States, the vulnerability of any given Census unit is relative to the rest of the country. That is, when values are ranked or represented as deviations from the mean it is in respect to the United States as a whole. For the SVI derived here, tract data are grouped by county so that the vulnerability of any given tract is relative to its respective county. Details within the county become clear and this makes it so that the spatial relationships are at an actionable scale. For example, county planners can visually analyze which tracts are vulnerable within the respective jurisdiction and propose strategies accordingly.

\subsection{SOCIAL VULNERABILITY INDEX (SVI)}

ACS data for 2008-2012 was collected for the 15 vulnerability indicators outlined in the CDC method (Table 2). While certain indicators are directly obtained from the ACS, others must be derived from a combination of original Census variables, such as percent minority population. Also, important to note, the indicator data used in this methodology may be obtained in more than one way. That is, the ACS variables occur redundantly throughout numerous tables in the Census database. For example, the indicator for mobile homes appears both in the "Group housing” and "Household type by units in structure” tables. Because of this, the same indicator may either be drawn from a sum value from various reported subsets in one or various tables, or a direct total. In theory, these should agree. For this methodology, an attempt was made to obtain the indicators as directly as possible in respect to the database available in a local server.

All variables are normalized to their respective domains except for income (i.e. expressed as percentages, per capita, or other density functions). Tracts with 0 population values are omitted from analysis. The data is grouped by Census county GEOID (Geographic Identifier) and values for each indicator are ranked from lowest to highest (1 being the lowest), except for income which is ranked in reverse since it has a negative relationship with vulnerability. Ranks are converted to percentiles using the following formula where $x_{i}$ is any individual value and $n$ is the number of records:

$$
\text { Percentile rank }=\frac{\left(x_{i}-1\right)}{(n-1)}
$$

Percentiles for select indicators are summed into composites according to each Theme (see Table 2 for which variables correspond to each Theme). These totals are then scaled so that all values range from 0 to 1 (i.e. unity-based normalization; $\mu$ represents the mean for a given variable):

$$
z_{i}=\frac{x_{i}-\mu}{x_{\max }-x_{\min }}
$$

Finally, the Themes are summed to obtain the overall combined SVI, scaled to range $0-1$, and concatenated to spatial files by GEOID. Spatial files are exported in 30-meter grid-cell raster format in order to be compatible in the Urban-CAT environment (i.e. GeoTIFF).

\subsection{CLIMATE-INDUCED SOCIAL VULNERABILITY INDEX (CSVI)}

To obtain the CSVI, the previously calculated SVI will be combined with a Climate Index. Since all indicators and indices including the SVI are in raster format, they can be added to each other in a matrixstyle operation. Once all datasets are scaled to range from 0 to 1, the resultant SVI calculated for East Tennessee is added one-to-one to the climate indicators to produce the final CSVI:

$$
[S V I]+[\text { Climate Index }]=\text { CSVI }
$$


This addition will be rendered dynamically as a user selects SVI Themes and Climate Index indicators to consider. However, the data itself remains static. That is, the values for each grid cell in the Theme and overall combined SVI and Climate Index indicator rasters are maintained.

\subsection{DATA-IMPOSED LIMITATIONS \& UNCERTAINTIES}

It is worth noting that each variable in the SVI and Climate index will be taken to be of equal weight and not proportioned to any degree since doing so would introduce greater subjectivity. This subjectivity would require a tortuous justification for each weight given as a comprehensive reference for weighing these components is not yet clear. However, the 4 Themes somewhat address this as it allows for the observation of which broad characteristics are contributing to the overall score. For example, a user may identify an area with a high CSVI, view each Theme individually, and discover that Housing \& Transportation is the main factor.

Likewise, the summation of the SVI to the climate index isn't weighted for the same reason. However, other methods of combining the data were entertained including a Multiplicative and Maximum Method, for example:

$$
\begin{aligned}
& (S V I) *(\text { Climate Index })=\text { CSVI } \\
& (0.0) *(0.9)=0.00 \\
& (0.5) *(0.5)=0.25 \\
& (0.1) *(0.9)=0.09 \\
& (0.3) *(0.3)=0.09
\end{aligned}
$$

In the multiplicative cases above, a CSVI score lower than either factor is produced by multiplying SVI and Climate Index scores. Moreover, in cases where a Theme or the overall combined SVI has a 0 value, multiplication would produce a 0 score CSVI, as in case $\{1\}$. This could be particularly heinous in the Minority Status \& Language Theme where several tracts have a 0 value for this Theme, and would potentially skew results as other indicators are engaged or manipulated.

Cases $\{3\}$ and $\{4\}$ produce significantly different scores although the factors would sum to the same value. Despite the Climate Index value being very high in case $\{4\}$ compared to either value in case $\{5\}$, the CSVI scores are the same due to the implicit effect of the magnitude of high and low values in multiplication.

Another possible approach is a Maximum Method which takes the higher of the two values. This would undermine the rationale for an SVI as the output would be the selection of either a high physical vulnerability or a high social vulnerability and not both as a compound impact:

$$
\begin{aligned}
& \max \{(0.1),(0.9)\}=0.9 \\
& \max \{(0.7),(0.9)\}=0.9
\end{aligned}
$$

Both cases above would have the same CSVI score despite equation $\{7\}$ having a significantly higher social vulnerability. Thus, the Additive Method is maintained to preserve the assumption that the two indices have an additive relationship to climate vulnerability: 


$$
\begin{aligned}
& (0.1)+(0.9)=1.0 \\
& (0.7)+(0.9)=1.6 \\
& (0.3)+(0.3)=0.6
\end{aligned}
$$

Another note on the production of the SVI is that actual population or population density is not factored into the CSVI itself. That is, CSVI scores for any given tract are to be independent of the total population of the tract. However, to discern between two tracts of similar CSVI score, or to highlight populous tracts which are highly vulnerable, population data can be superimposed if desired.

\section{RESULTS}

\subsection{MAPPED RESULTS FOR SVI}

Results for the overall combined SVI are mapped by county in Figs. 3a-k (See Appendix A for results of each SVI Theme by county). By the additive nature of the methodology, scores approaching the value 1 describe a greater social vulnerability whereas scores approaching 0 describe a lesser vulnerability to environmental impacts. For the SVI, it is readily apparent that some counties may experience a significantly greater SVI variance than others (e.g. Monroe vs. Knox counties). Additionally, a clustering of vulnerable tracts is evident in some counties. Two tracts with 0 population values were found, which

coincide with the tracts that bound a Smoky Mountain National Park and Oak Ridge National Laboratory, both of which have significant footprints and which are very unlikely to have any known permanent housing. 

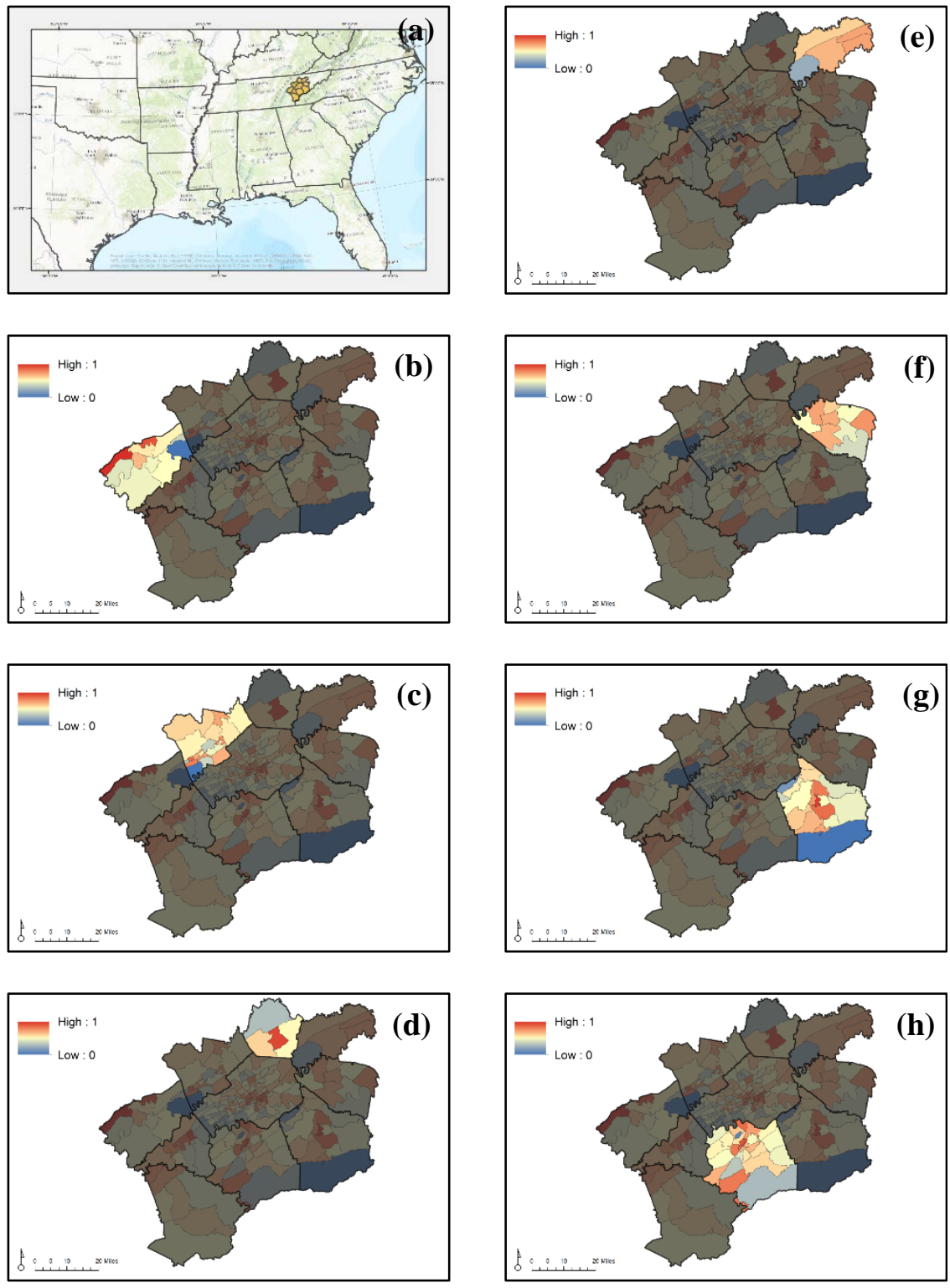
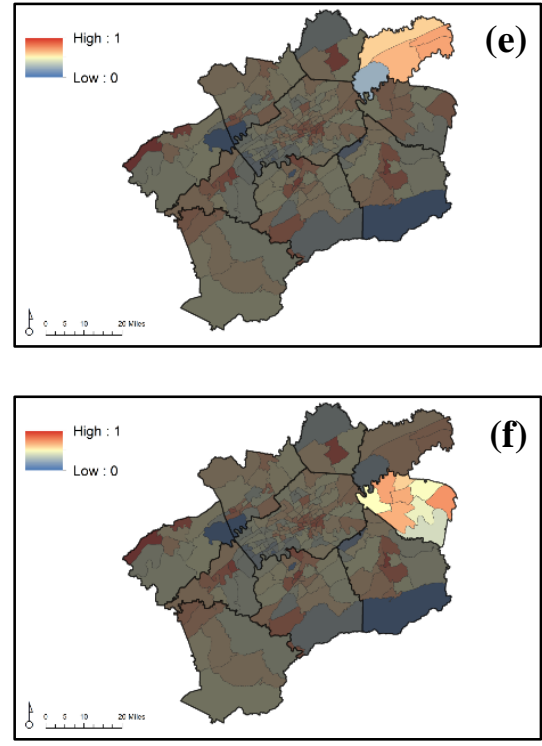

(e)
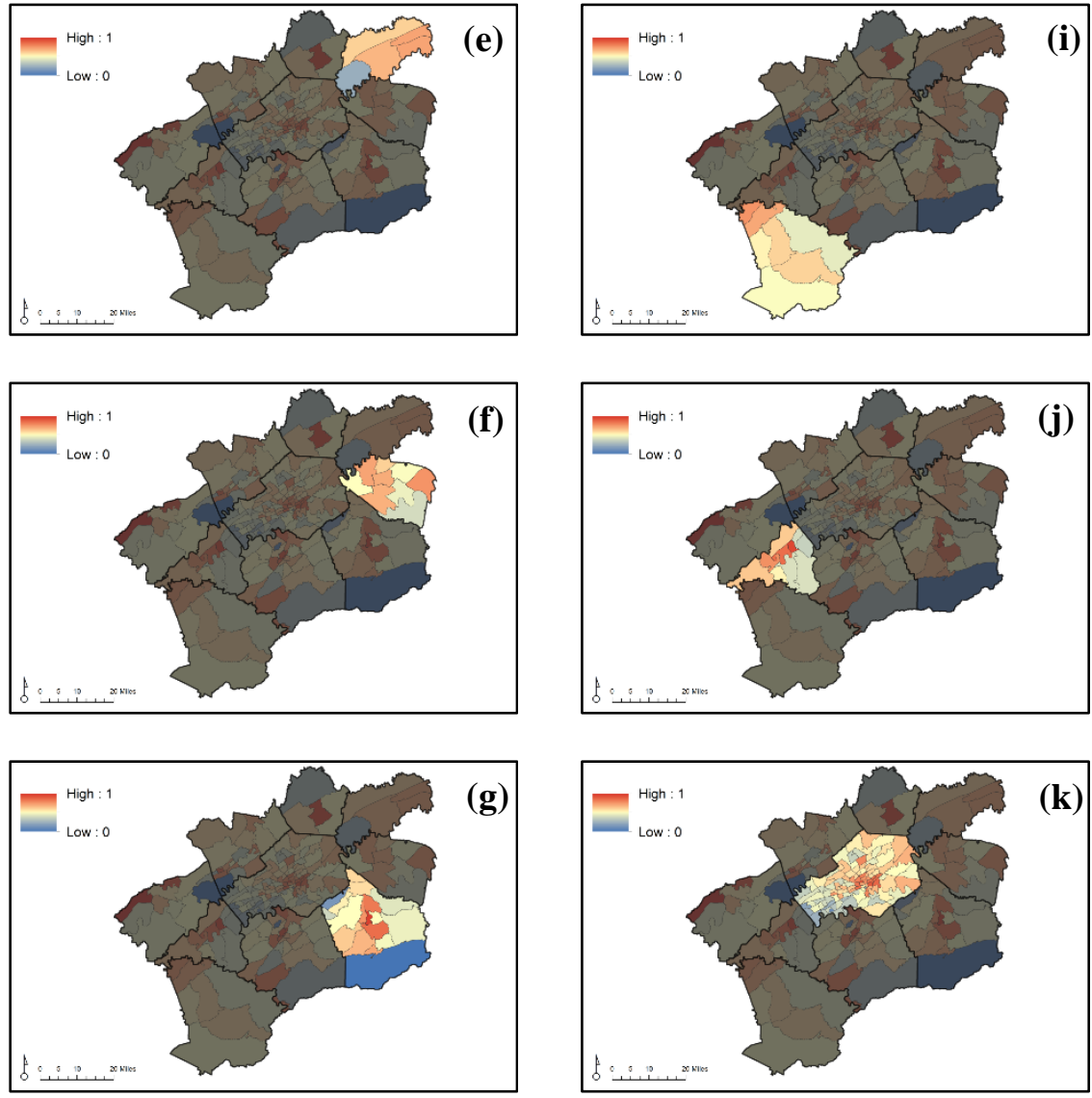

Fig. 3. (a) Location and extent of East Tennessee area of interest, and mapped result of the overall combined SVI for (b) Roane County (c) Anderson County (d) Union County (e) Grainger County (f) Jefferson (g) Sevier County (h) Blount County (i) Monroe County (j) Loudon (k) Knox County. SVI scores approaching 1 describe a greater social vulnerability whereas scores approaching 0 describe a lesser vulnerability. 


\subsection{INCORPORATION OF SVI AND CSVI RESULTS INTO URBAN-CAT}

Results for the SVI and CSVI are dynamic and will reside within the Urban-CAT web environment. Since the SVI was added to the Climate Index one-to-one, values for the CSVI can range from 0 to 2 where an index of 2 describes a greater vulnerability to climate impacts. Exporting the SVI and CSVI as a raster dataset allows not only for compatibility with the backend of the tool, but also facilitates the real-time analytical computation as the user manipulates parameters. Each raster cell in the web visualization represents the index values in geographical respect to each Census tract (Figure 4). Likewise, the cells of the remaining indicators in Urban-CAT, which share a common format and resolution, have per-cell values in geographic space. These datasets can then be synthesized within the computational environment to produce cartographic visualizations for analysis. In this way, not only are the SVI and Climate Index combined in real-time, but other available datasets can also be superimposed. Additionally, the user can continuously choose different scenarios and parameters to analyze various possibilities and potential impacts.

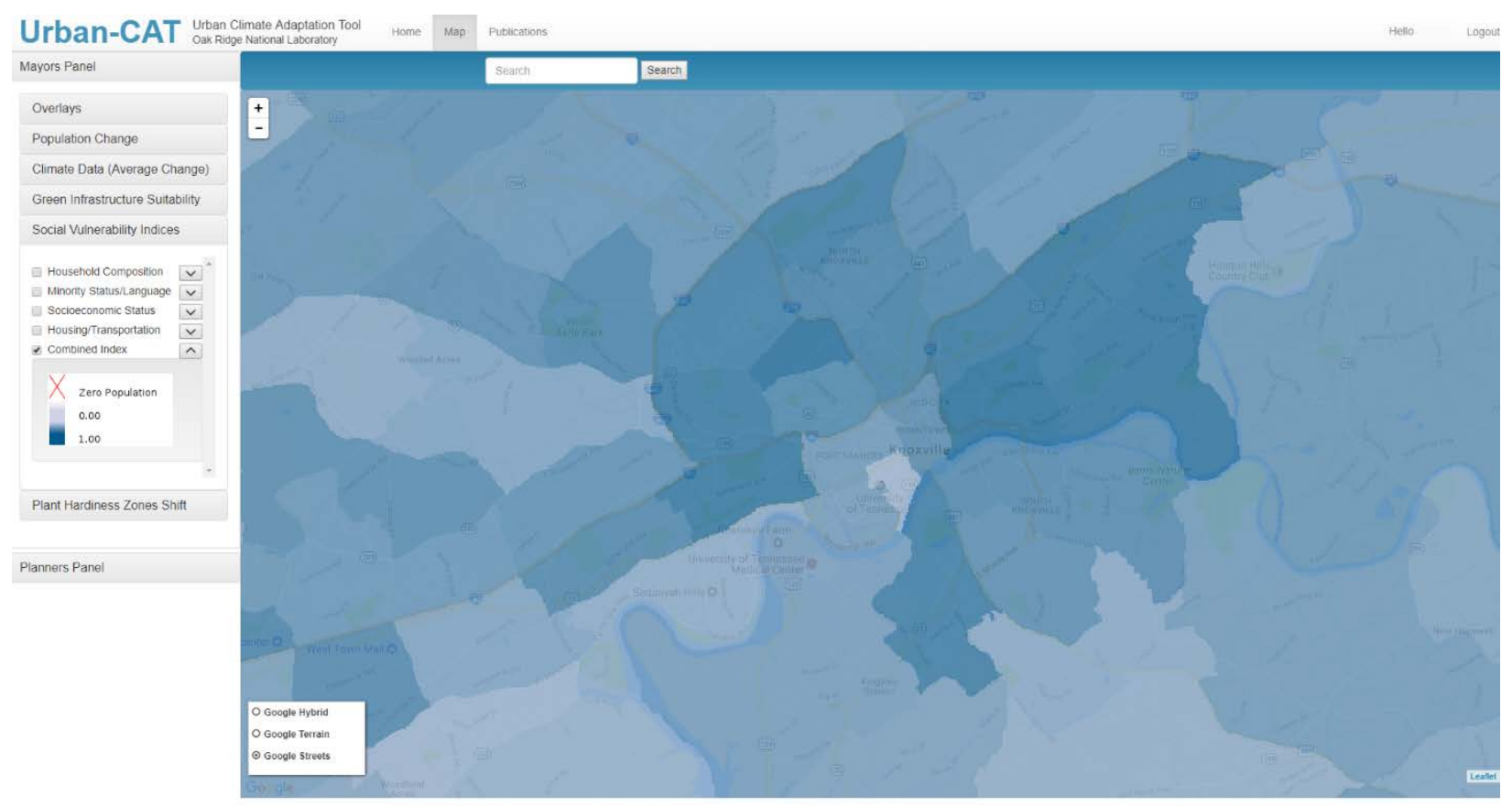

Fig.4. Overall combined SVI shown for downtown Knoxville, Tennessee as displayed in Urban-CAT.

\subsection{DISCUSSIONS \& ASSUMPTIONS}

This methodology can be scaled to higher administrative boundaries or span the entire United States where the county grouping can be either maintained or adapted. For example, the groupings could be completed by state for the U.S. to focus on state-level mitigation for the country. Also, future improvements may be made to this initial index, including a revision with more context-specific indicators (e.g. climate change vs. flooding vs. drought).

A few assumptions are taken in the production and use of the SVI indicator for Urban-CAT. Use of the CSVI along with projected climate data within the Urban-CAT environment should be mindful we are combining historical data with projected data, and so we assume a static social dynamic and that these components of social vulnerability will not change in the future. Additionally, a variable that may be an 
indicator for vulnerability today may not be one in the future, and new indicators and data opportunities may emerge.

\subsection{IMPLICATIONS OF SOCIAL VULNERABILITY IN IMPLEMENTATION STRATEGIES}

Green Infrastructure is a form of urban Green Space along with parks, forests, streams, community gardens, and others. Although the target benefit of GI is stormwater capture, as a form of green space it also collaterally serves several other ecological and social benefits, such as air filtering, noise reduction, and physical and psychological benefits to communities in proximity to these spaces (Wolch, 2014). For example, urban green space has been shown to reduce mortality, obesity, and improve psychological conditions for residents in close enough proximity. Because of this, implementation of GI affects the distribution of green space amongst communities, and thus, the distribution relative social and ecological benefits.

Additionally, green spaces can affect a neighborhood's housing costs in a somewhat paradoxical fashion. While implementation of green spaces generally help to increase property values, and therefore has the appeal of improvement, there are cases where housing costs rise beyond the reach of the incumbent community (Wolch, 2014; Krueger, 2007). Cities in the recent past have taken the opportunity for large GI projects which have inadvertently caused displacement of communities, and the ensuing public health and safety issues. A staple example of this is the New York City High Line Park, where an abandoned elevated train line was converted to an aerial greenway, and set off "rounds of gentrification" as housing prices and rent skyrocketed (Wolch, 2014).

Georgetown University's Climate Center outlines several resiliency tools and reports that incorporate equity and social vulnerability, including the Environmental Protection Agency's Environmental Justice Screening and Mapping Tool (EJSCREEN), and other city-level initiatives. Additionally, they also offer informational resources for beginning GI adaptation initiatives. The National Institute of Standards and Technology (NIST) also has a community resilience planning guide. We note a trend in community based adaptation measures that consider social dynamics, and couple adaptation strategies with equity principles in prospect of an altogether more resilient outcome. In any case, a mindfulness of these dynamics may increase the success and public approval of GI projects, reduce potential of emergent issues, and possibly offer collateral benefits. 


\section{REFERENCES}

1. Centers for Diseases Control and Prevention (CDC). "SVI 2014 Documentation”. 2016. https://svi.cdc.gov/Documents/Data/2014_SVI_Data/SVI2014Documentation.pdf

2. Cutter, Susan L. "Vulnerability to Environmental Hazards”. Progress in Human Geography. 20(4): 530. 1996. http://webra.cas.sc.edu/hvri/docs/Progress_Human_Geography.pdf

3. Cutter, Susan L., Bryan J. Boruff, W. Lynn Shirley. "Social Vulnerability to Environmental Hazards”. Social Science Quarterly. 84(2). 2003. DOI: 10.1111/1540-6237.8402002

4. U.S. Environmental Protection Agency (EPA). “EJSCREEN Technical Documentation”. 2015. https://www.epa.gov/ejscreen/technical-documentation-ejscreen

5. Flanagan, E. Barry, Edward W. Gregory, Elaine J. Hallisey, Janet L. Heitgerd, Brian Lewis. “A Social Vulnerability Index for Disaster Management”. Journal of Homeland Security and Emergency Management. 8:1. 2011. http://gis.cdc.gov/grasp/svi/A\%20Social\%20Vulnerability\%20Index\%20for\%20Disaster\%20Man agement.pdf

6. Henstra, D. "Toward the climate-resilient city: Extreme weather and urban climate adaptation policies in two Canadian provinces”. Journal of Comparative Policy Analysis: Research and Practice. 14(2): 178. 2012. http://dx.doi.org/10.1080/13876988.2012.665215

7. Krueger, R. D. (2007). The Sustainable Development Paradox: Urban Political Economy in the United States and Europe. New York: Guilford Press.

8. Sylvester, Linda. M., Olufemi Omitaomu, Esther Parish. “Analyzing the Implications of Climate Data on the Rainfall Frequency Spectrum: Case Study of Knoxville, Tennessee and Surrounding Region”. Technical Report ORNL/TM-2016/485. Oak Ridge National Laboratory. 2016. Available at: http://info.ornl.gov/sites/publications/files/Pub69819.pd

9. Sylvester, Linda. M., Olufemi Omitaomu, Esther Parish, Melissa Allen. "Processing and Monthly Summaries of Downscaled Climate Data for Knoxville, Tennessee and Surrounding Region”. Technical Report ORNL/TM-2016/486. Oak Ridge National Laboratory. 2016. Available at: https://wiki.ornl.gov/sites/publications/Files/Pub69821.pdf

10. Wolch, R. J. (2014). Urban green space, public health, and environmental justice: The challenge of making cities ‘just green enough’. Landscape and Urban Planning, 125, 234-244. 


\section{APPENDIX A. MAPPED RESULTS FOR SVI THEMES}

SVI scores approaching 1 describe a greater social vulnerability whereas scores approaching 0 describe a lesser vulnerability. The 10 counties of the East Tennessee region are shown in detail for the four different themes.

\section{Socioeconomic Status Theme:}

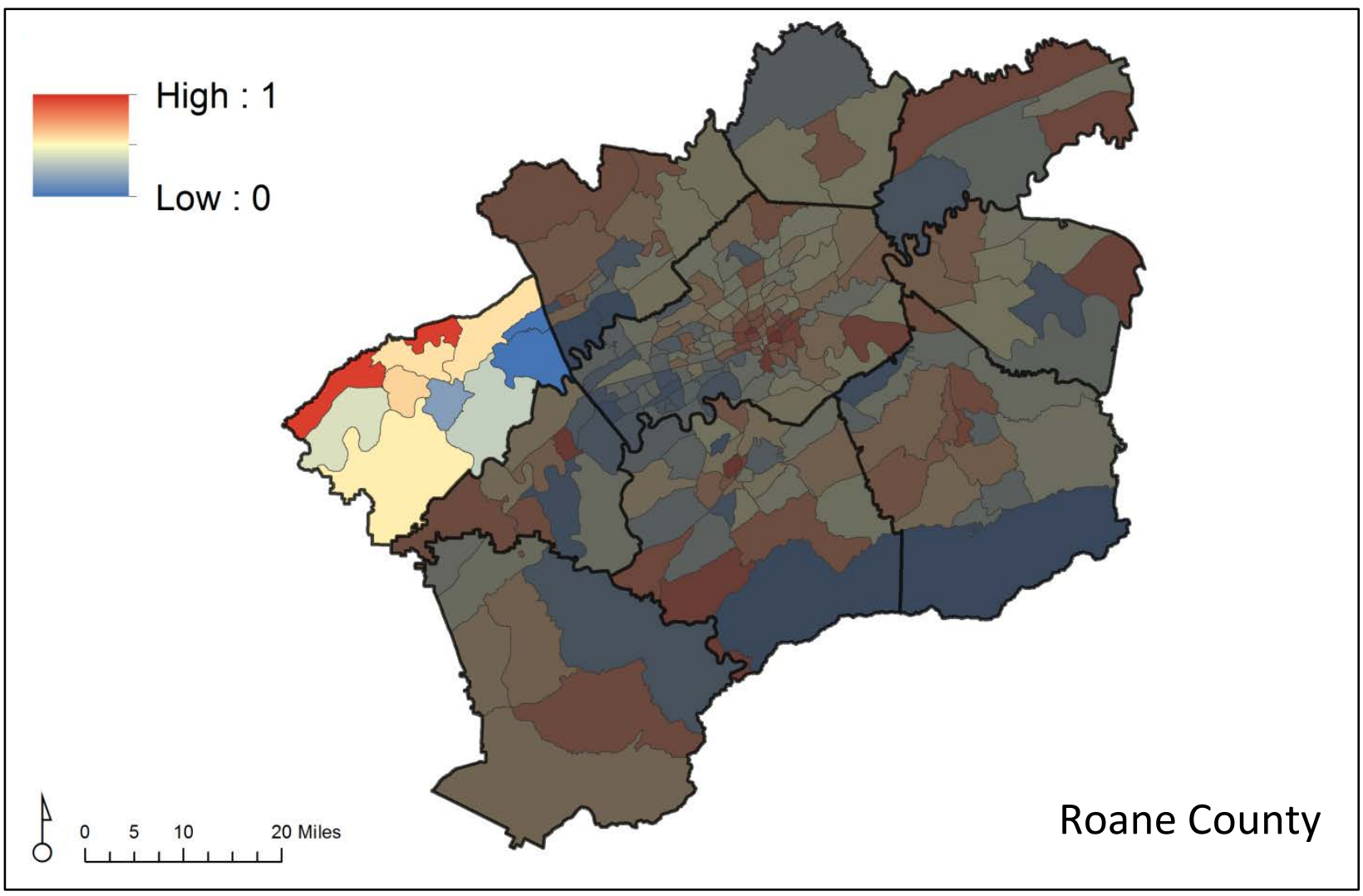



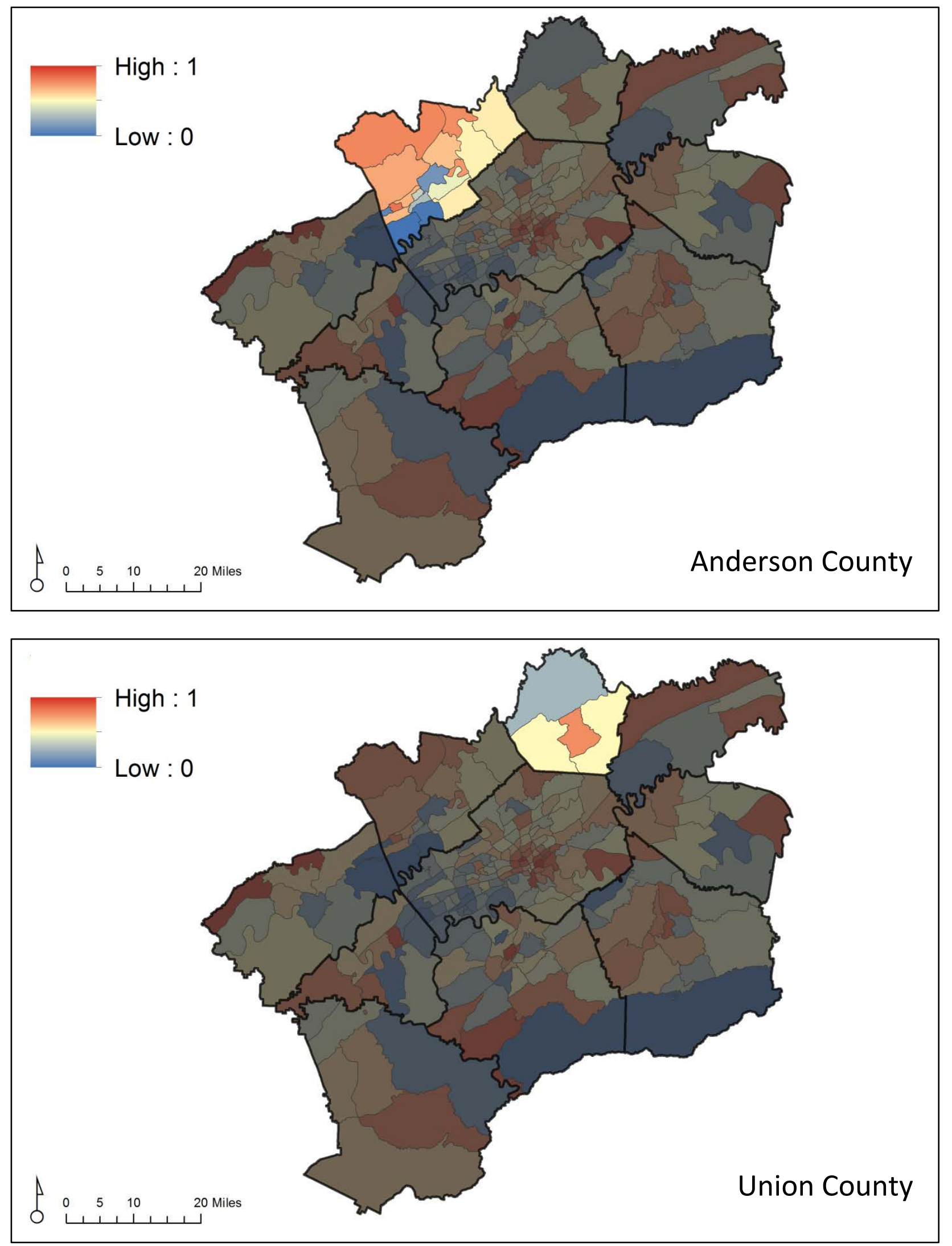

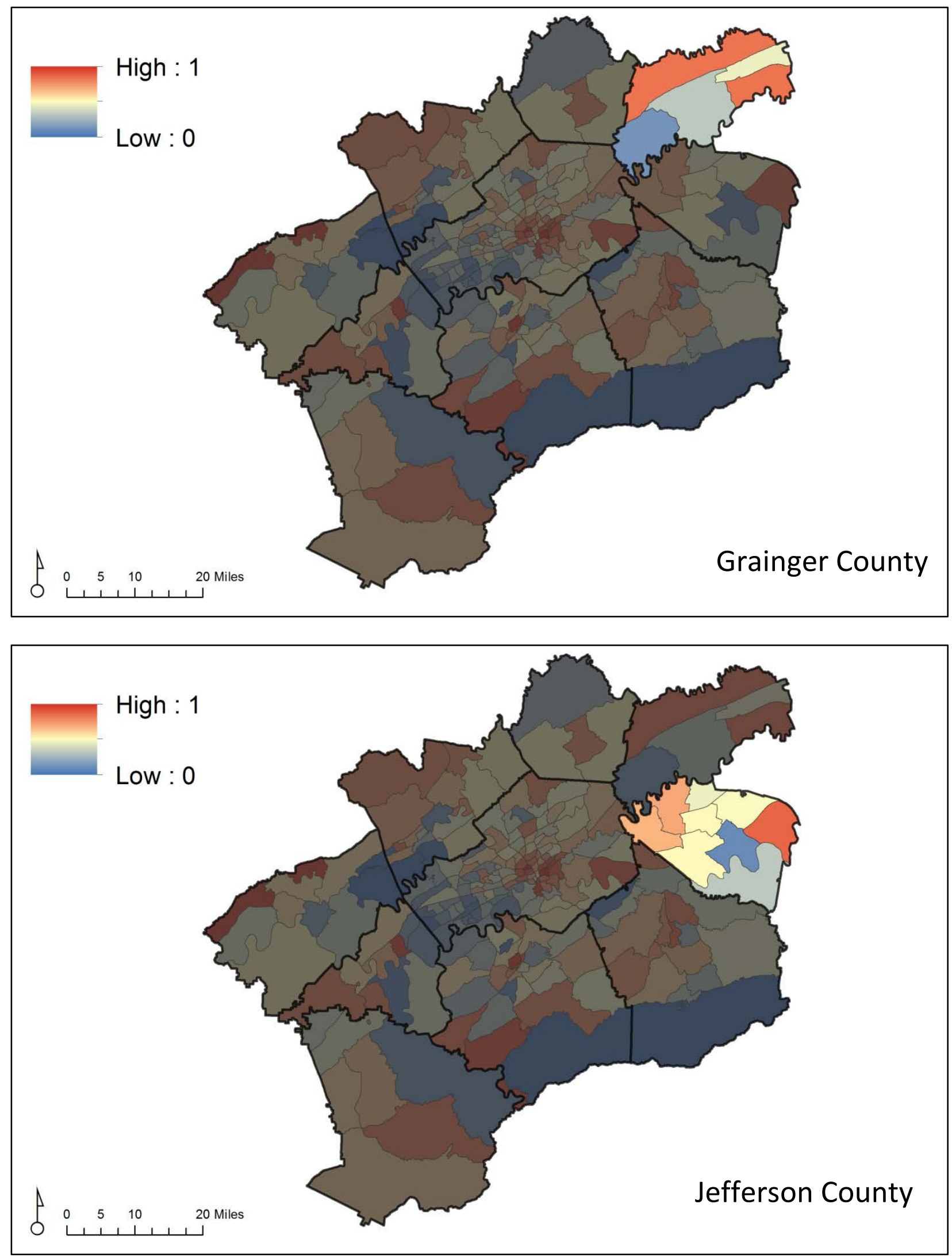

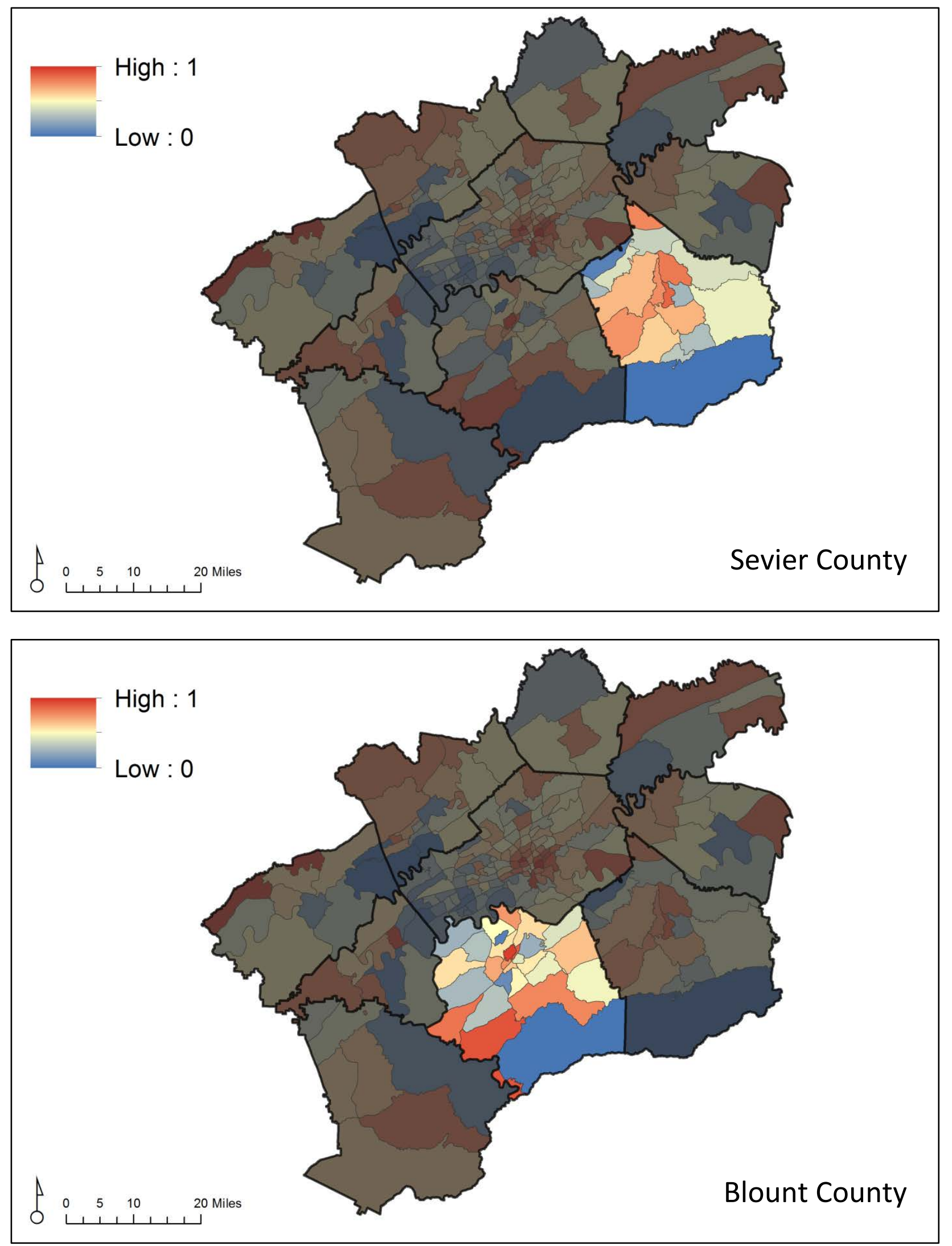

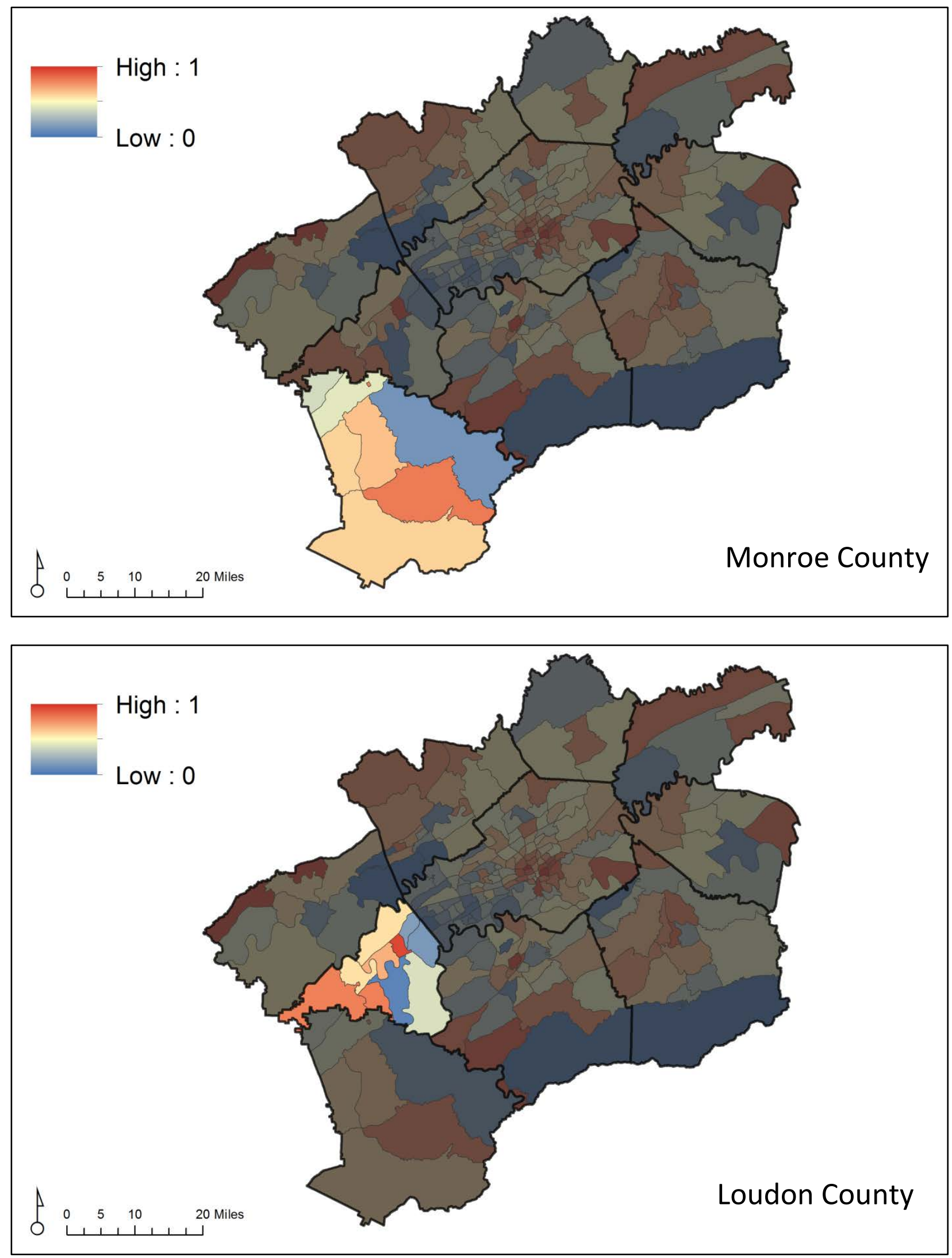


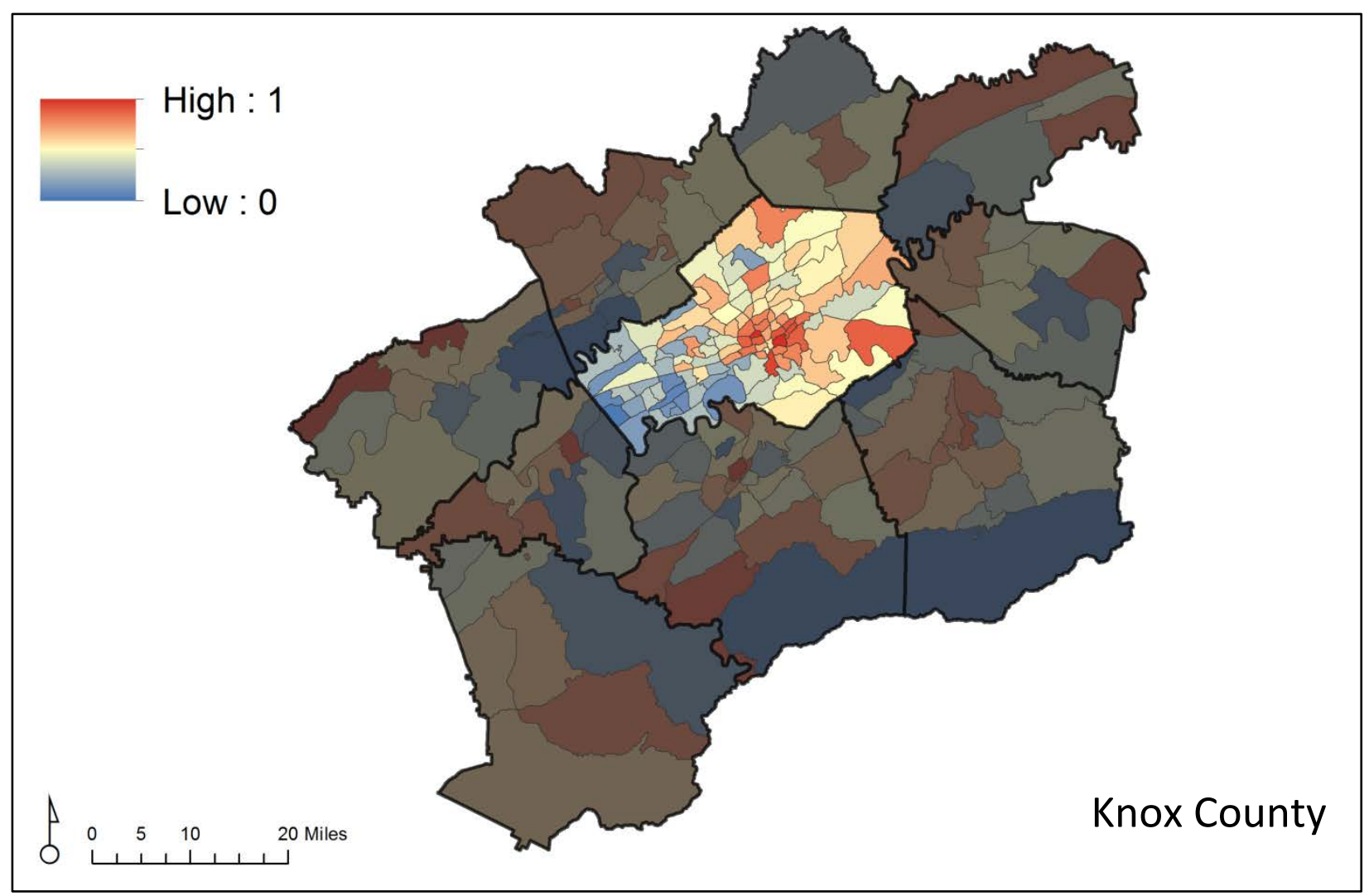


Household Composition \& Disability Theme:
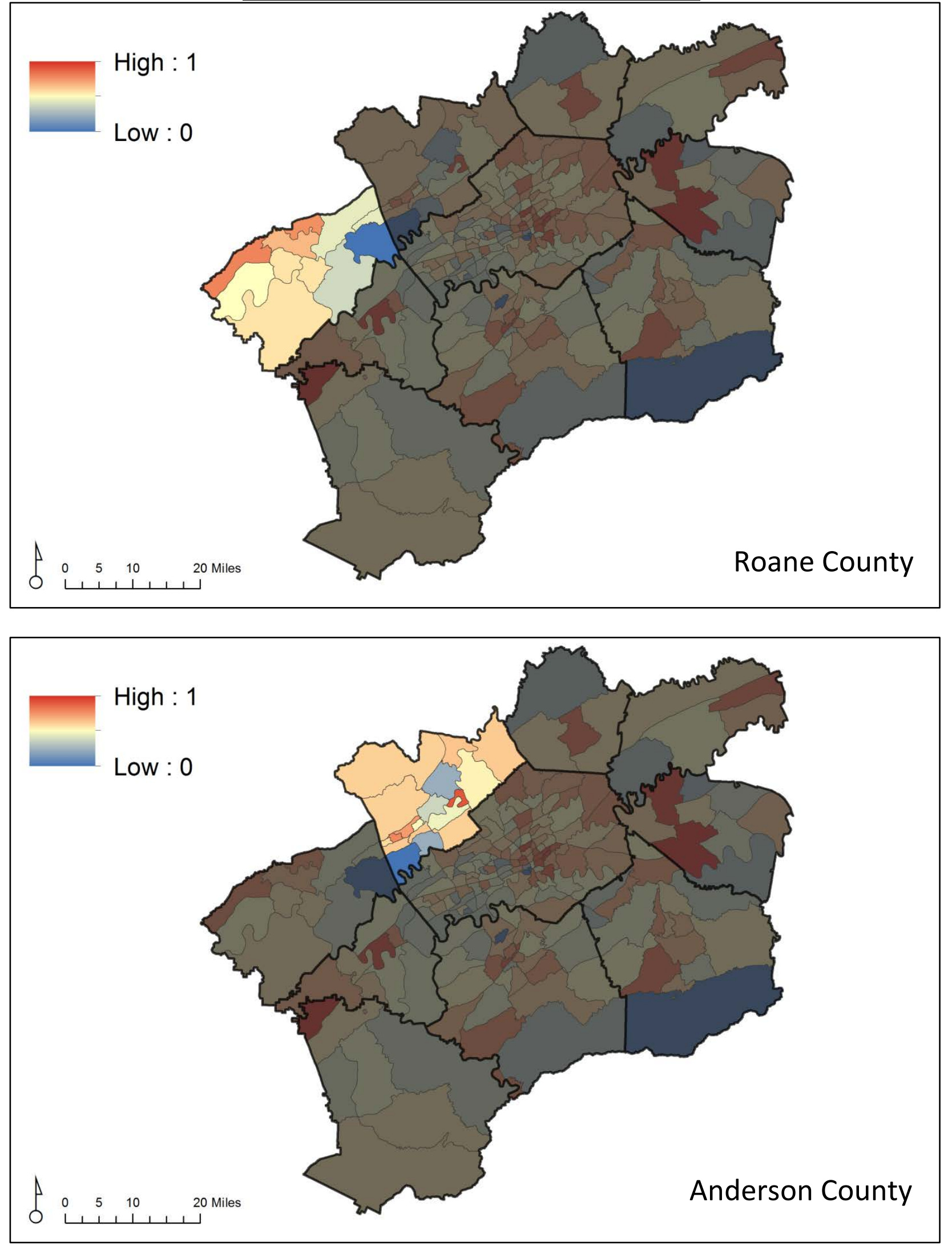

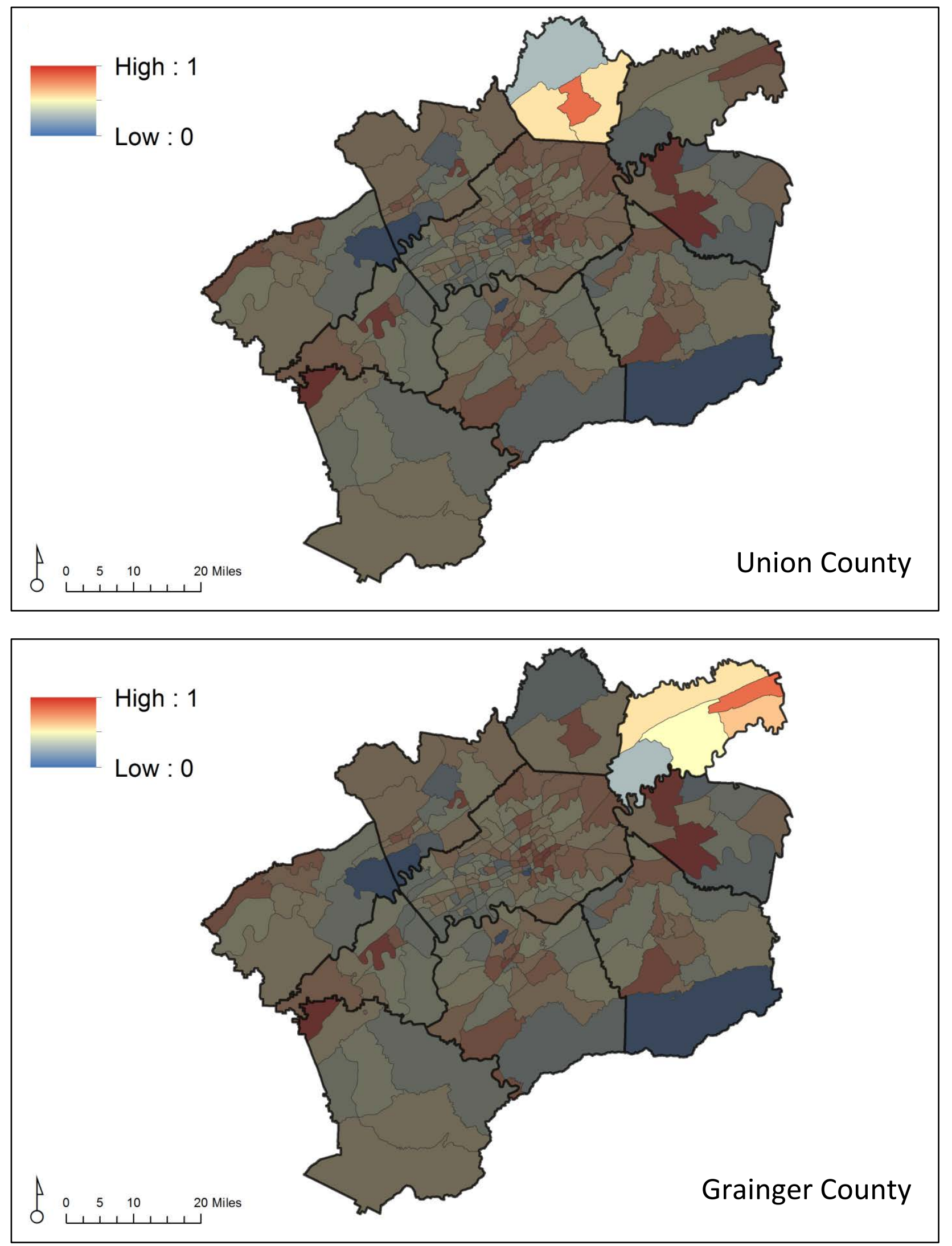

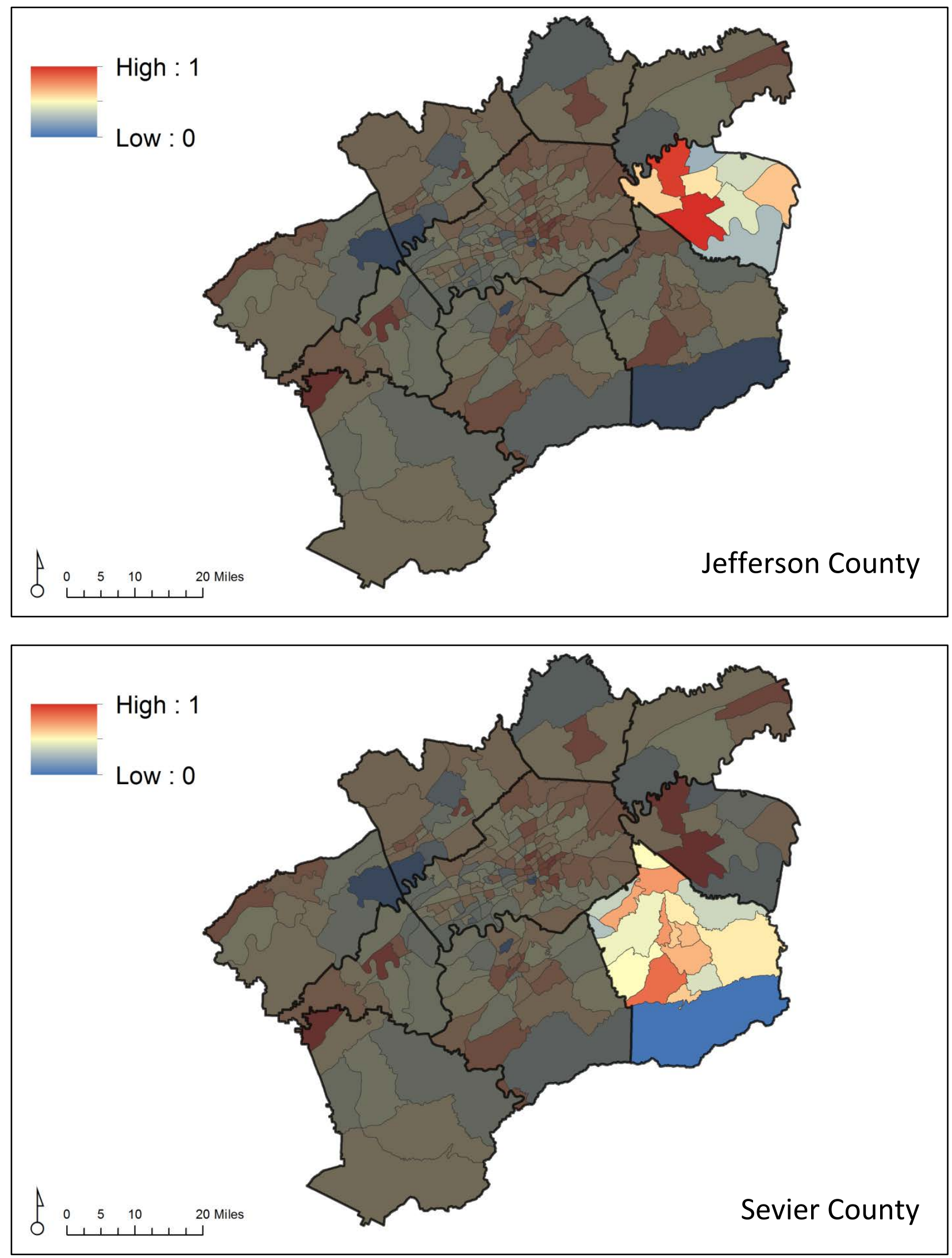

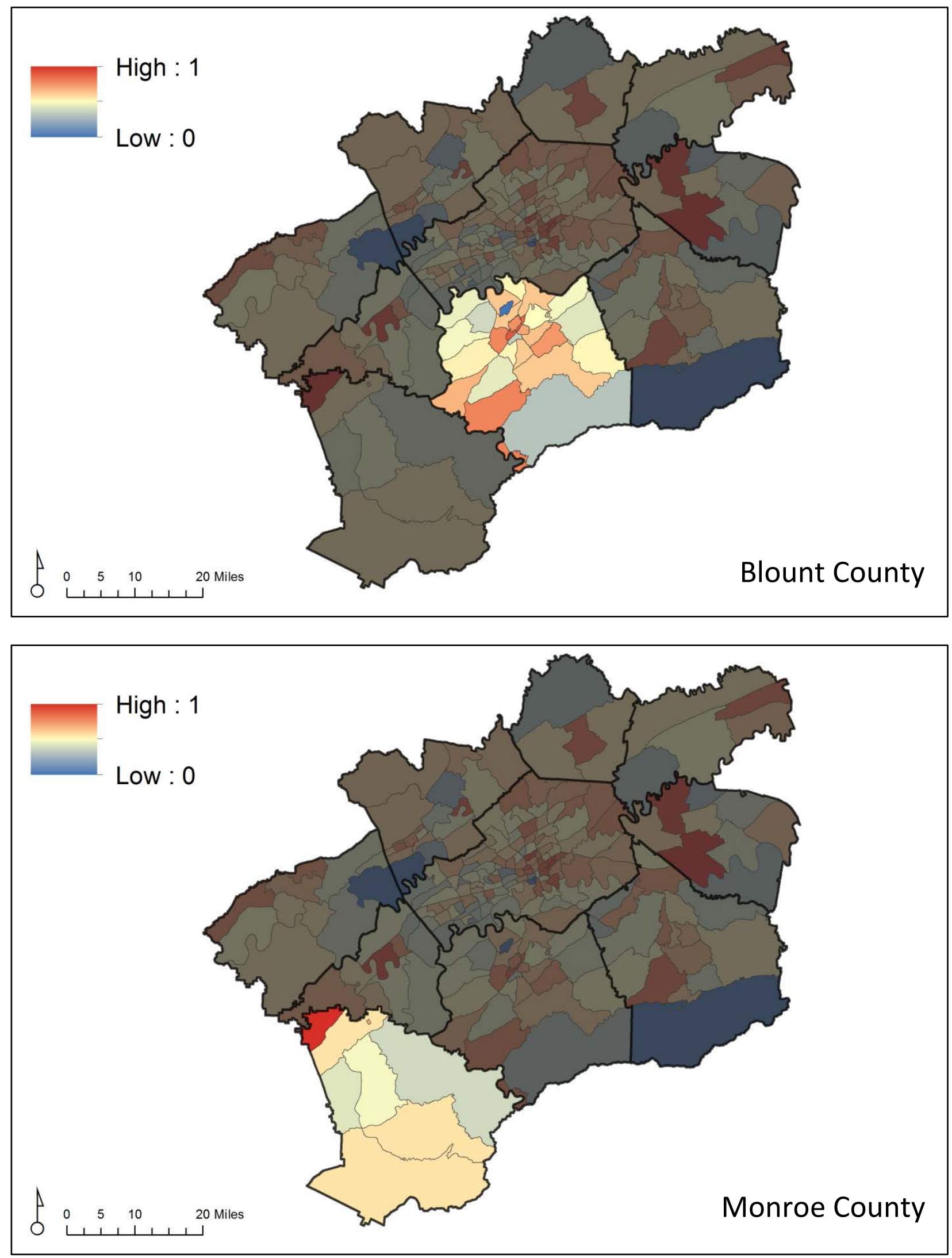

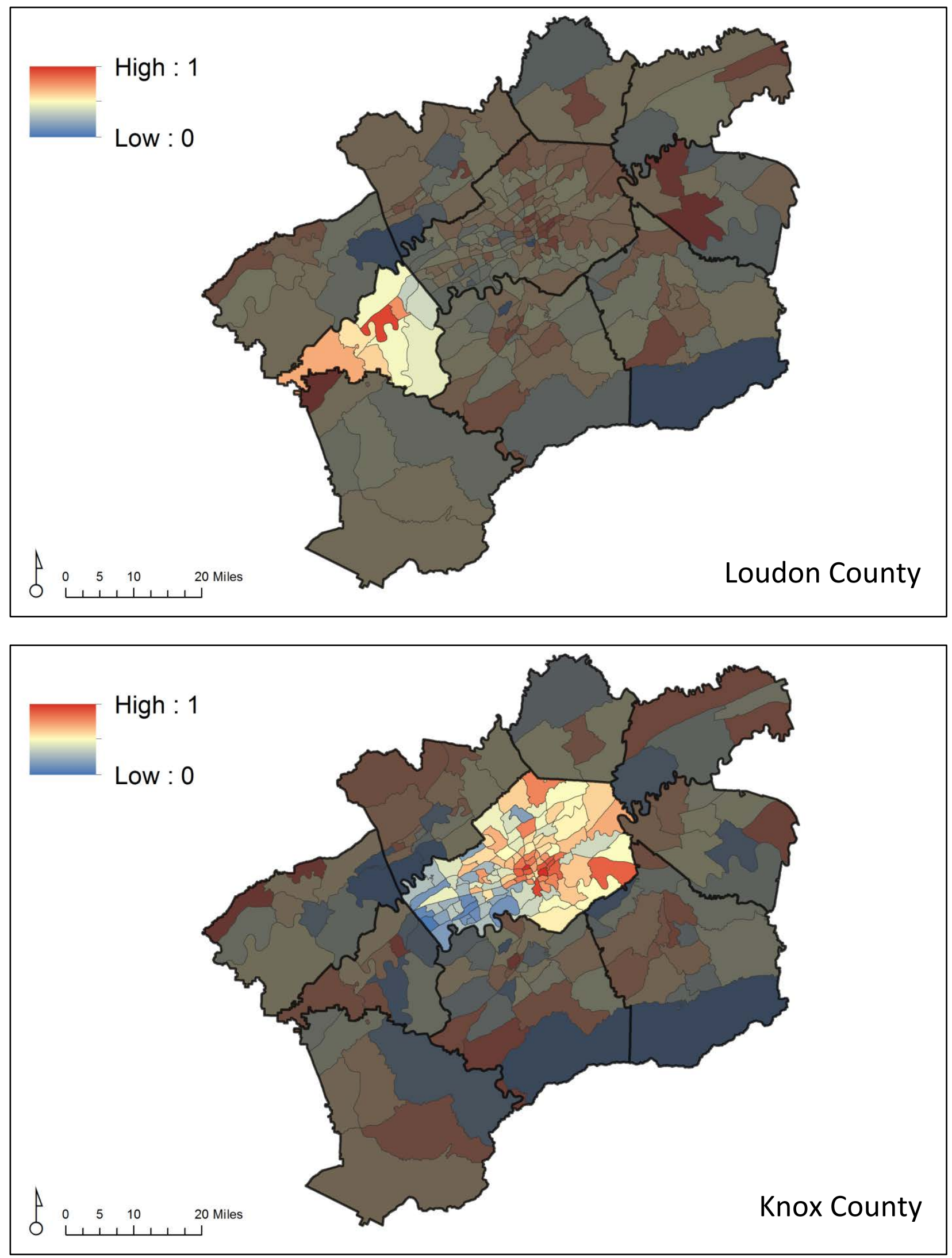
Minority Status \& Language Theme:
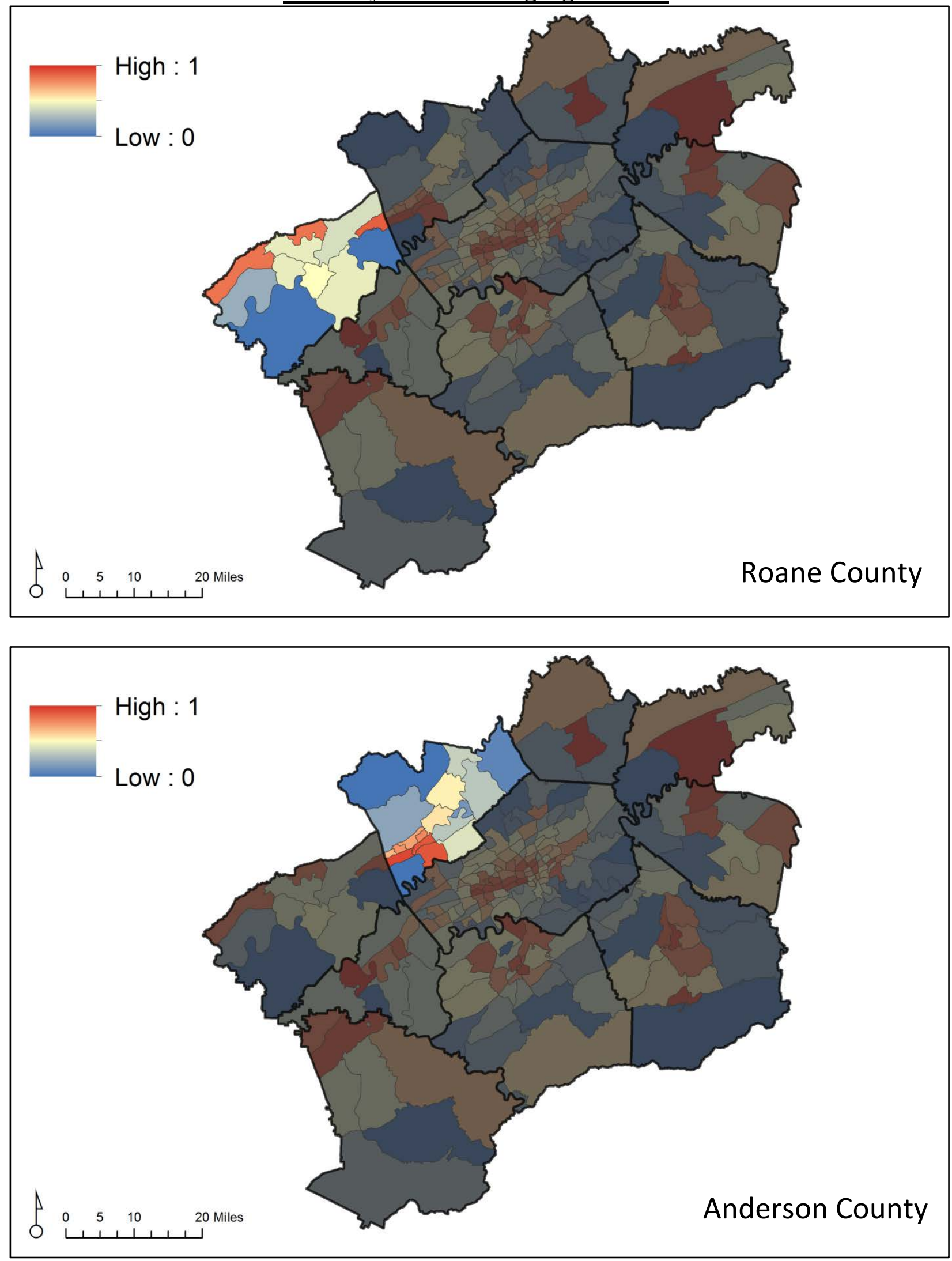

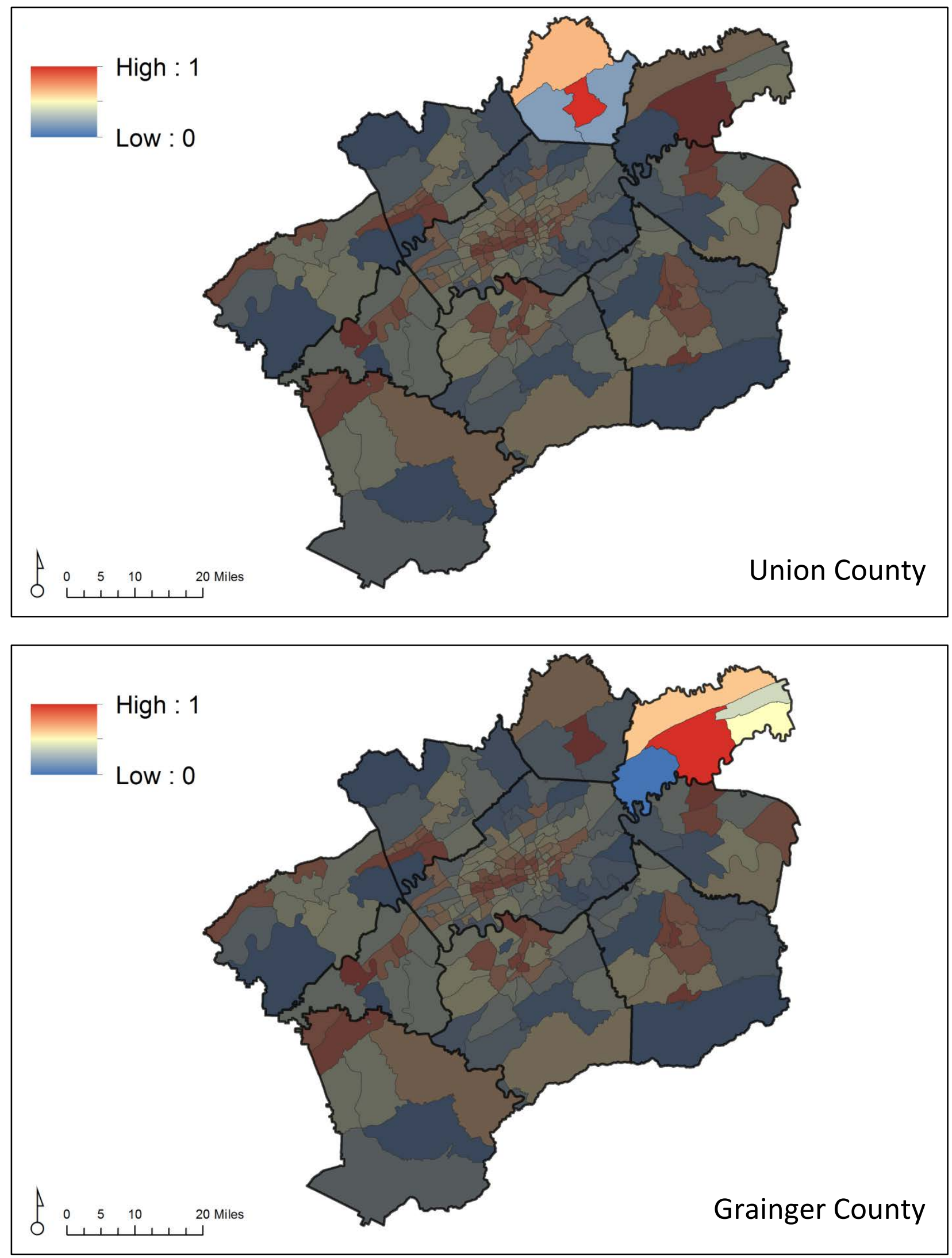

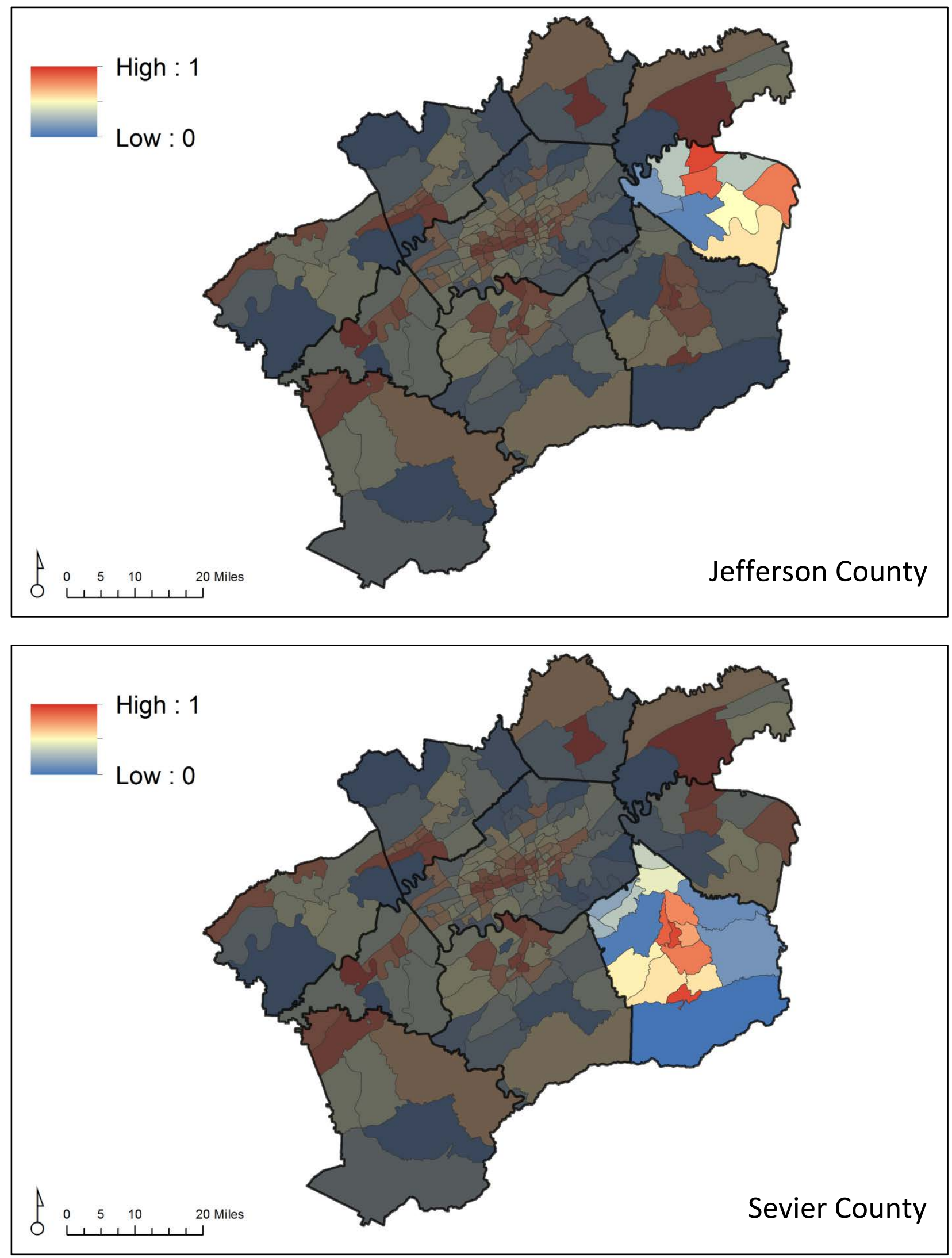

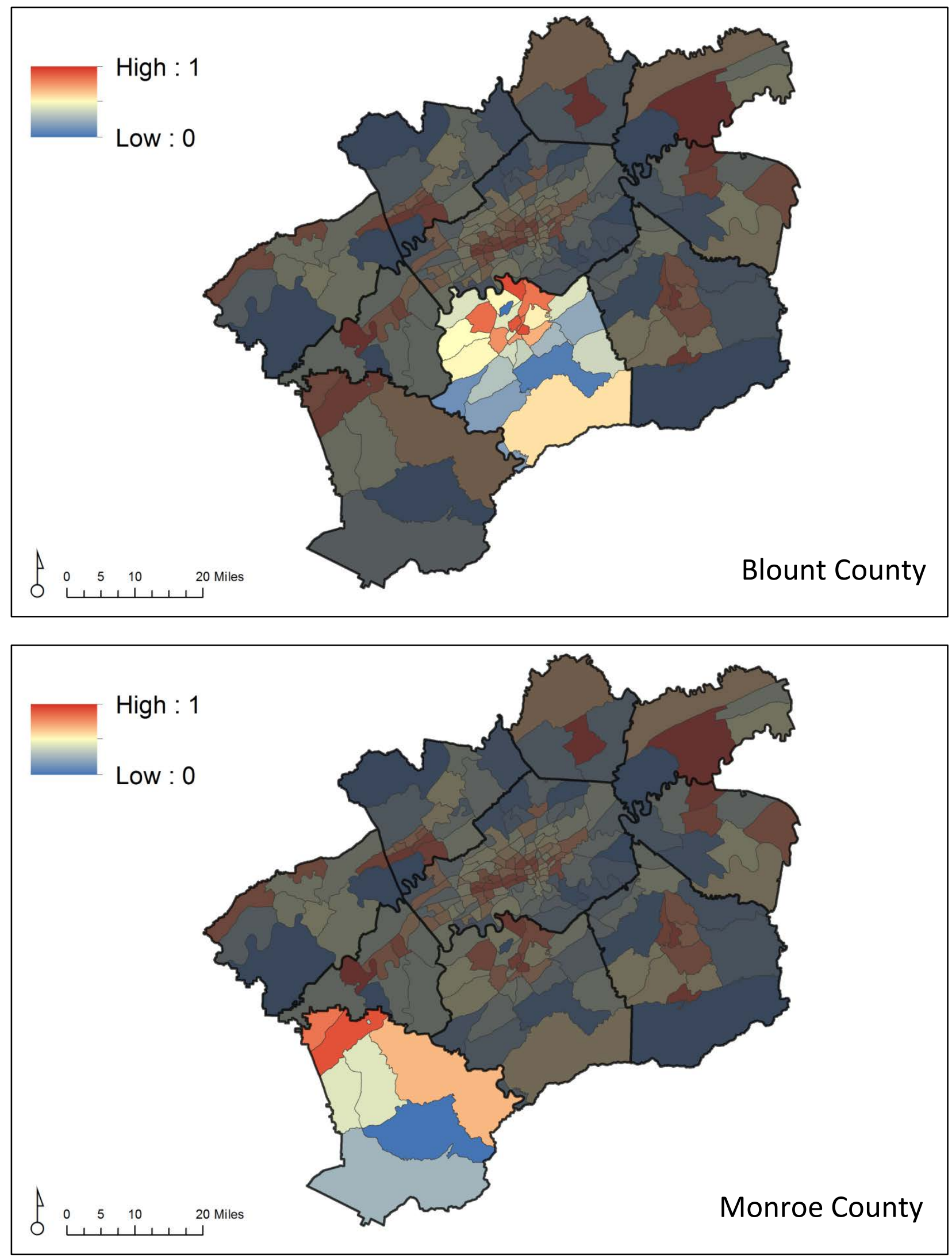

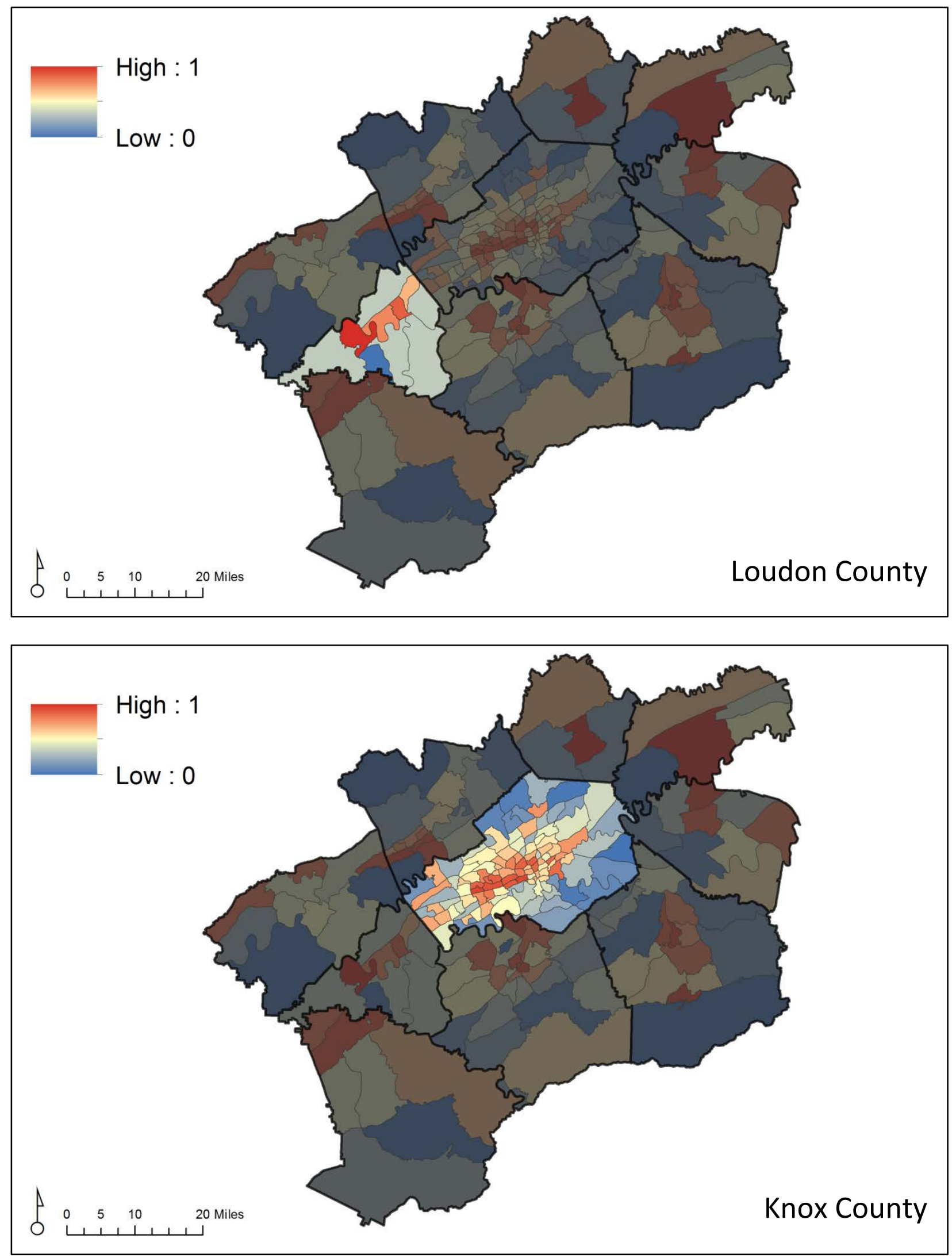
Housing \& Transportation Theme:
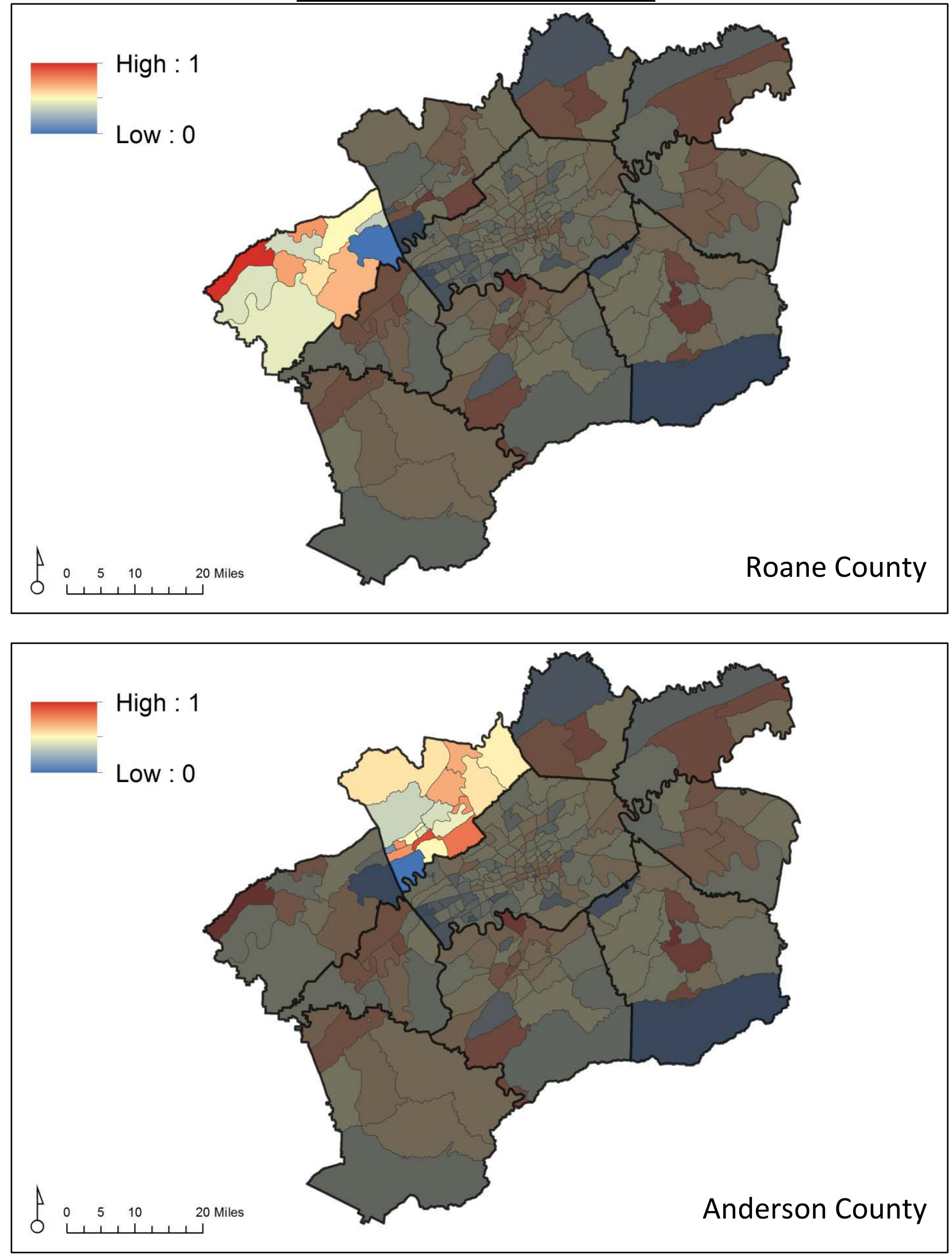

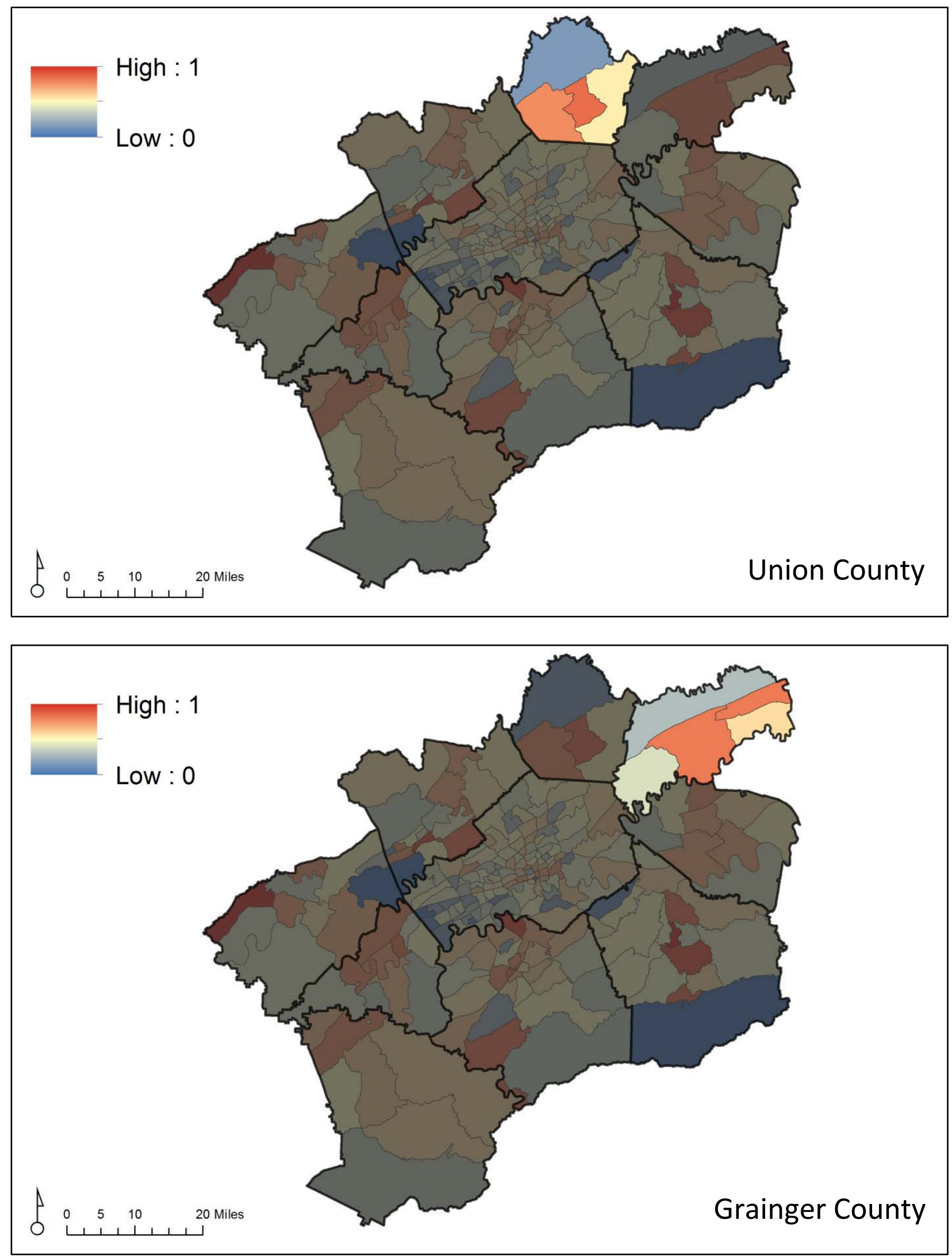

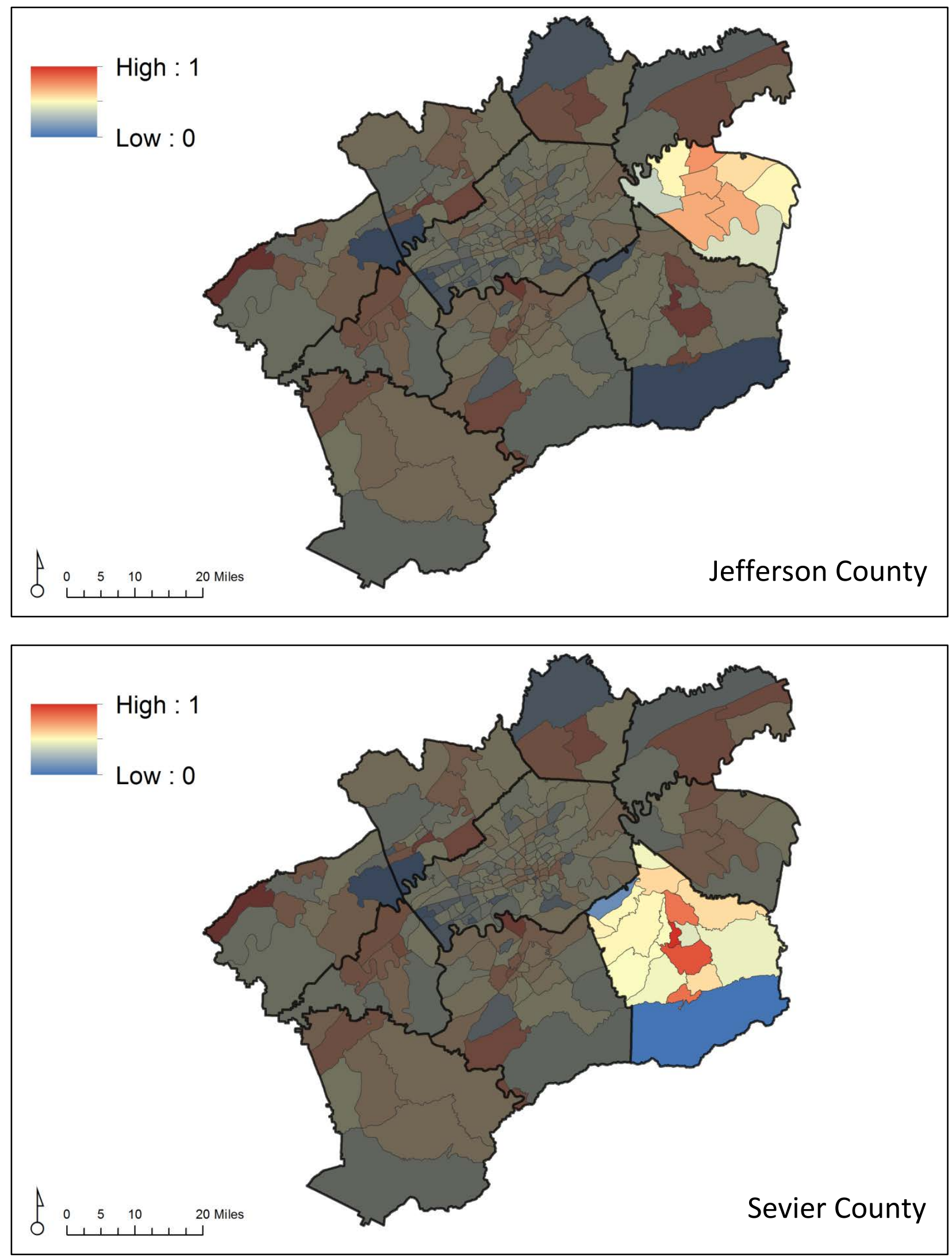

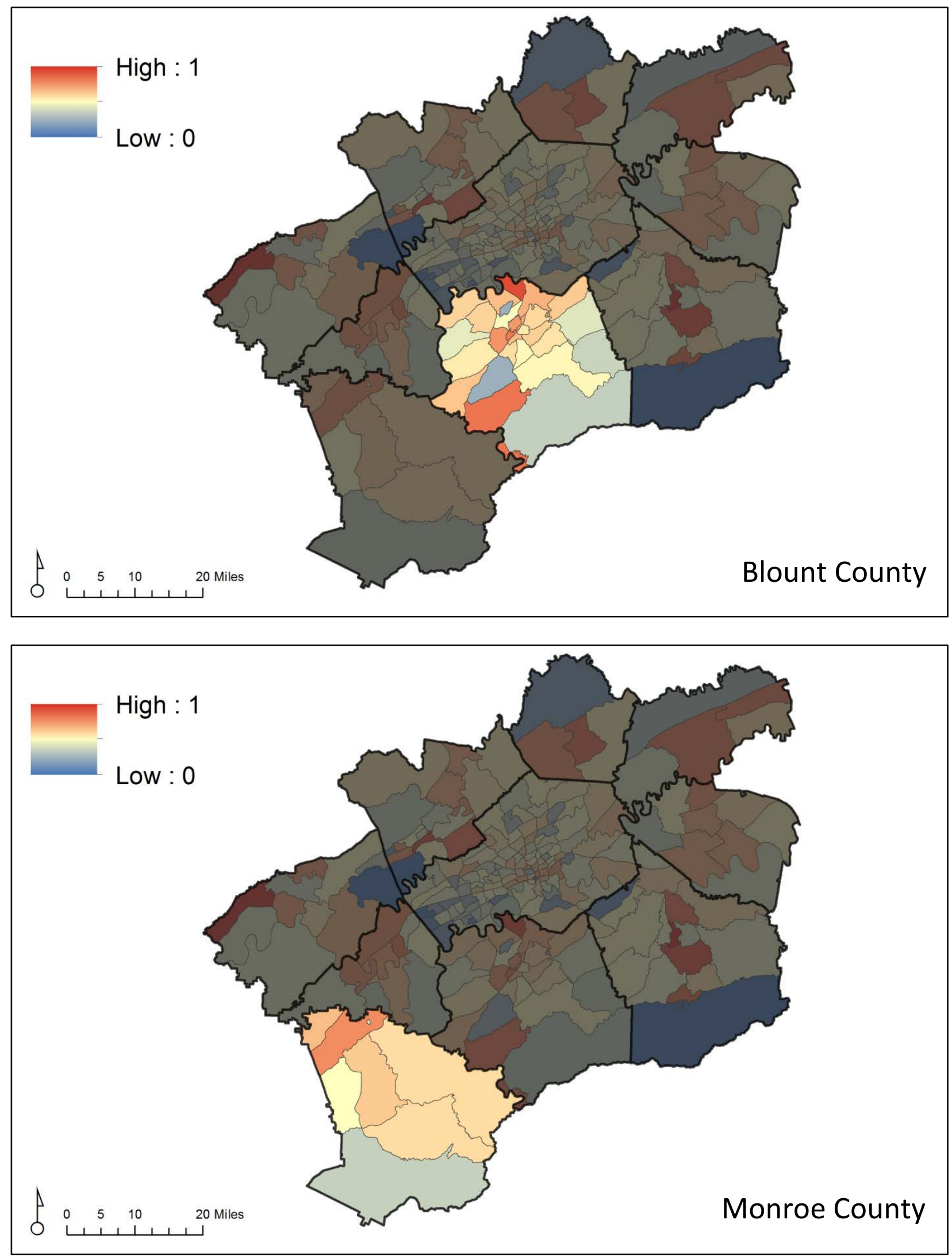

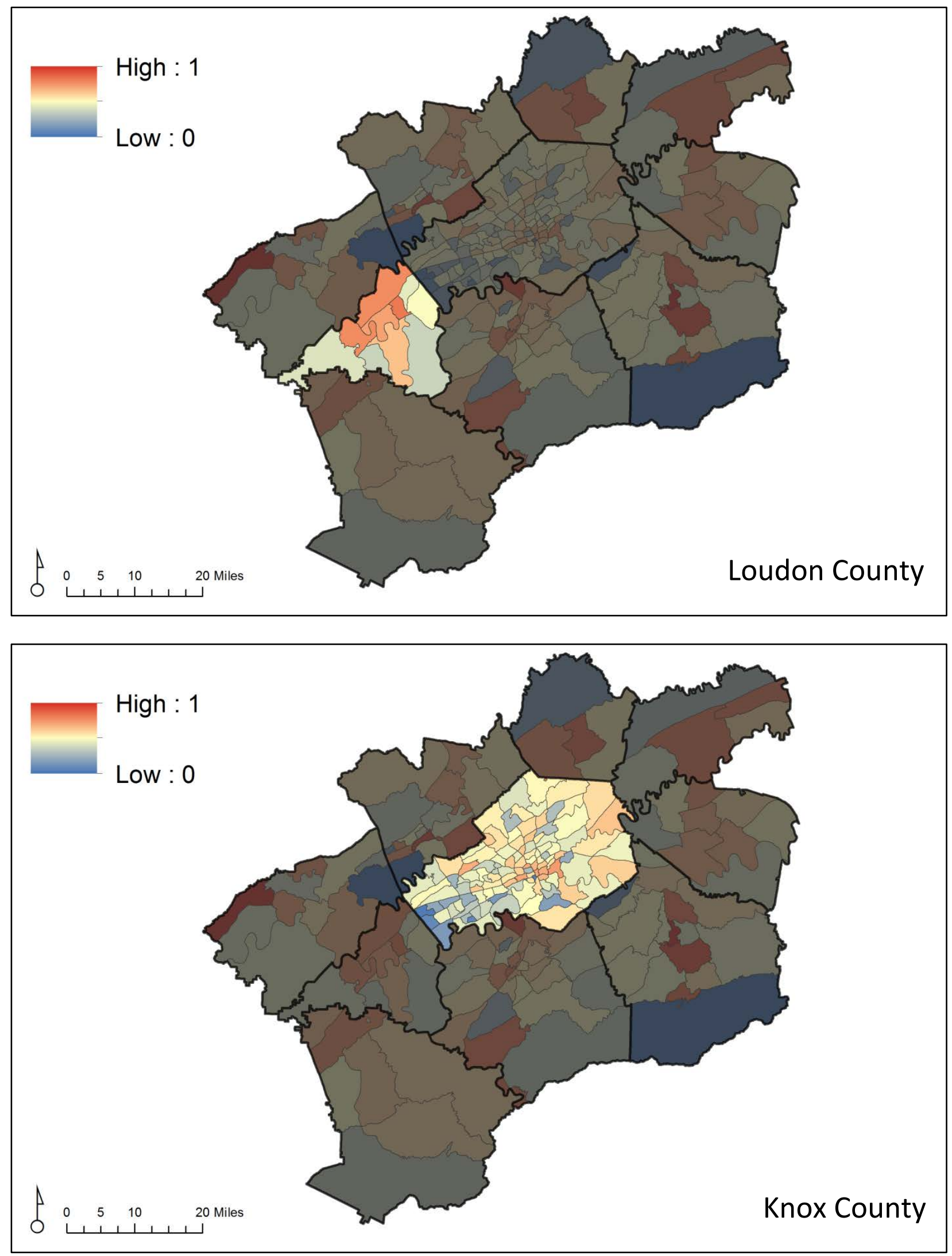